\title{
Krishna Baldev Vaid - twórca osobny
}

\author{
Jacek BĄKOWSKI*
}

JACEK ВĄкоWsкi studiował matematykę i informatykę na Université Pierre et Marie Curie w Paryżu, absolwent filologii indyjskiej w Instytucie Orientalistyki na Uniwersytecie Jagiellońskim. Jego zainteresowania naukowe obejmują językoznawstwo porównawcze indoeuropejskie, przekładoznawstwo, szczególnie $\mathrm{z}$ hindi-urdu, oraz językoznawstwo kognitywne. Obecnie pracuje nad semantyką dystrybucyjną zapożyczeń persko-arabskich we współczesnym języku hindi oraz nad komputerową analizą stylistyki starożytnych tekstów sanskryckich.

iD https://orcid.org/0000-0003-2480-3396

E-MAIL: jacek.bakowski@alumni.uj.edu.pl

Krishna Baldev Vaid ${ }^{1}$ urodził się 27 lipca 1927 roku w Indiach Brytyjskich, w miejscowości Dinga w Pendżabie, na terenach

* Autor składa serdeczne podziękowania prof. dr hab. Lidii Sudyce oraz dr. Piotrowi Borkowi z Zakładu Języków i Kultur Indii i Azji Południowej Instytutu Orientalistyki UJ za pomoc oraz liczne uwagi w zakresie przekładu.

1 Z różnych wariantów: spolszczenie (Kriszna Baldew Waid), transkrypcja naukowa (Krș̣̣a Baldev Vaid), wybieram formę zangielszczoną, idąc w ślady innych tłumaczy, np. Annie Montaut, która pisała o nim w języku francuskim i na ten język tłumaczyła jego utwory. Indyjscy twórcy często używają takiej właśnie formy w różnych obszarach przestrzeni publicznej, dlatego przejmują ją później badacze ich twórczości, niezależnie od tego, czy piszą w języku angielskim, czy w innych językach nieindyjskich. Ponadto pod tym nazwiskiem Krishna Baldev Vaid publikował w języku angielskim (np. zbiory tłumaczeń na język angielski dzieł własnych), a więc można przyjąć pisownię bez spolszczenia, podobnie jak w nazwiskach Joyce czy Dickens. Tę zasadę zastosuję również w przypadku innych indyjskich twórców. 
dzisiejszego Pakistanu. W 1947 roku, po podziale subkontynentu, przeniósł się z rodziną do Indii. Studiował anglistykę na Uniwersytecie Pendżabskim w Czandigarhu², a w 1964 roku uzyskał doktorat na Uniwersytecie Harwarda, specjalizując się w twórczości Henry'ego Jamesa. Od tego czasu wykładał zarówno na uczelniach indyjskich, jak i amerykańskich. Po przejściu na emeryturę w 1985 roku wrócił do Indii. W 2010 roku osiadł na stałe w Nowym Jorku. Przez całe życie Vaid trzymał się z dala od literackiego establishmentu i nigdy nie otrzymał żadnej nagrody literackiej. W 2010 roku Hindi Academy przyznała mu co prawda prestiżową nagrodę Shalaka Samman, ale wycofała nominację po tym, jak pisarz został oskarżony o nieprzyzwoitość przez urzędnika Kongresu (Saumya 2010).

W 1957 roku zadebiutował powieścią Uskā bacpan (Jej dzieciństwo). Jest autorem dziesięciu powieści, piętnastu zbiorów opowiadań i siedmiu sztuk teatralnych. Swoje traumatyczne przeżycia związane z podziałem subkontynentu opisał w książce Guzrā Huā Zamānā (Czas miniony), wydanej w 1981 roku.

Krishna Baldev Vaid znany jest również jako tłumacz klasycznych dzieł literatury anglosaskiej na język hindi, m.in. Czekając na Godota czy Alicji ${ }_{W}$ krainie czarów. Interesujące w jego karierze literackiej jest to, że niektóre ze swych utworów pisanych w hindi przełożył na angielski; w Stanach Zjednoczonych ukazały się jego książki pt. Steps in the Darkness oraz The Broken Mirror. Dzieła Vaida były tłumaczone na francuski³ ${ }^{3}$ niemiecki, włoski, rosyjski i japoński. Dotychczas nie publikowano przekładów jego dzieł w Polsce. Autor zmarł 6 lutego 2020 roku w Nowym Jorku.

\section{Specyfika języka autora}

W jednym ze swoich wywiadów ${ }^{4}$ Vaid tłumaczył, jak dokonał wyboru języka, którym się posługuje w swojej twórczości. Jego językiem ojczystym był pendżabi,

2 Pierwotnie Uniwersytet Pendżabski miał siedzibę w Lahaurze, na terenach dzisiejszego Pakistanu. Po 1947 roku uniwersytet podzielił się na dwie niezależne od siebie instytucje. Aby je rozróżnić, władze postanowiły zmienić zapis nazwy „Pendżab”: po stronie indyjskiej Panjab University z siedzibą w Czandigarhu, a w Pakistanie University of the Punjab w Lahaur.

3 Na szczególną uwagę zasługuje praca Annie Montaut, która od lat zajmuje się jego twórczością i przetłumaczyła na język francuski powieści Guzrā Huā Zamānā (fr. Requiem pour un autre temps), Māyālok (fr. La splendeur de Maya), opowiadanie Līlā (fr. Lila), sztuki teatralne Bhūkh āg hai (La faim, c’est le feu), Parivār akhārāa (fr. Famille en bataille), Hamārī buṛhiyā (fr. Notre vielle dame) oraz zbiór opowiadań Pichle janm kī bāt hai (fr. Histoire de renaissances).

4 "I did not want to write in English, even though I was fairly good in it and knew that I'd get better, because I didn't consider it as an Indian language and did not dream in it. I didn't want 
ale uważał go za zbyt ubogi. Choć świetnie znał angielski, nie uznawał go za język indyjski i to wystarczyło, by odrzucił ten środek literackiej ekspresji. Pozostał mu więc wybór pomiędzy urdu - posługiwał się nim sprawnie, zapewne po części dzięki znajomości perskiego - a hindi, którego nauczył się samodzielnie. Pragnął udoskonalić swoją znajomość hindi i wykorzystując kompetencje językowe w zakresie urdu, dążyć do wypracowania własnego, oryginalnego stylu, który odróżniałby się od standardowych wersji tych dwóch języków5 5 .

Można więc uznać, że znajomość urdu miała dla niego decydujące znaczenie i była ważnym elementem jego stylu - używał w swojej twórczości zapożyczeń z urdu w sposób świadomy i przemyślany ${ }^{6}$. Zatem stosowanie urduizmów stało się znakiem rozpoznawczym Vaida, a specyfika tego języka wraz z jego urduizmami, które zatem miały wartość ekspresywną (Newmark 1988, 182), powinna być uwzględniana podczas tłumaczenia jego utworów na język polski ${ }^{7}$ i stanowić jeden z priorytetów tłumacza, a nawet dominantę translatorską.

„To, co moim zdaniem winno w tłumaczeniu pozostać” - pisze Anna Bednarczyk - „nazywać będę dominantą translatorską” i definiuje ją jako: „element struktury utworu tłumaczonego, który trzeba przełożyć (odtworzyć) w utworze docelowym, aby zachować całokształt jego subiektywnie istotnych cech”. Ponieważ te istotne cechy są subiektywne, można założyć, że każdy tłumacz i każdy krytyk uzna za istotną zupełnie inną cechę danego utworu. Co więcej, mogą się oni w tej kwestii nie zgadzać z autorem oryginalnego

to choose Punjabi as my medium of creative expression, even though it was my mother tongue, because I didn't consider it rich enough. The choice was between Urdu, which I was also good at thanks to my proficiency in Persian, and Hindi which I had almost entirely taught myself thanks to the similarity of its and Urdu's grammar and syntax. With more of Hindi reading and the help of a good dictionary and with an openness to Urdu and Persian for the enrichment of my vocabulary, I could forge a style of my own that might even be better than standard stultified Hindi, or Urdu for that matter. I soon was able to achieve a style of my own free from the stiffness of both standard Hindi and Urdu and also the simplistic hotch-potch of the so-called Hindustani" (Vaid 2017).

5 Definicja standardowej wersji w: Stasik 2008, 146-148.

6 Autor poświęcił temu zagadnieniu jedno krótkie opowiadanie, w którym przedstawił wyimaginowany dialog pomiędzy językiem hindi a urdu. W dialogu tym zwraca uwagę na użycie słów trudnych do zrozumienia dla większości czytelników hindijęzycznych (Vaid 2010, 54-60).

Opis zagadnienia trzeciego języka w przekładzie znajdziemy w: Kaźmierczak 2016.

8 Oddanie tych wszystkich niuansów jest problematyczne, co zauważyła Annie Montaut, która przełożyła część jego twórczości na język francuski: „Certain works may just be too loaded with untranslatable 'realia' and connotations like Sobti’s Mitro Marjani, or K.B. Vaid's Dusrā nā kōi, with the constant play on the Hindi/Urdu lexicon, popular and highly literate references, and be similarly judged as a by-product of Beckett in a French publisher's words, on the basis of its English translation" (Montaut 2016, 65-66). 
tekstu (Bednarczyk 2008, 13). Olga Czuruta twierdzi, że w „tekście, który miałby być uznany za wielokulturowy, wielokulturowość jest dominantą translatorską" (Czuruta 2015, 88).

W artykule opublikowanym po jego śmierci w „Indian Express” Vaid został określony jako „być może najbardziej zurduizowany pisarz hindi” (Bhardwaj 2020).

\section{Specyfika języka hindi}

Bogactwo leksyki współczesnej literackiej odmiany hindi opartej na dialekcie khari boli (kharī bolī) ujawnia się głównie w sferze zapożyczeń z języka urdu. Możliwość posługiwania się różnymi rejestrami daje autorom ogromne możliwości ekspresji i odzwierciedla niezwykłą różnorodność kulturową, tzw. terytorium języka hindi ${ }^{9}$. Specyfika języka, który jest nośnikiem takiej różnorodności, stwarza rozliczne trudności w pracy tłumacza dzieł literackich $\mathrm{z}$ hindi na języki z innego obszaru kulturowego, w tym na język polski.

Hindi posiada złożony źródłosłów i czerpie w głównej mierze z sanskrytu oraz - po części za pośrednictwem urdu - z języków perskiego, arabskiego i tureckiego. Często słowa z obu źródeł funkcjonują równolegle jako synonimy, stanowiąc pary znaczeniowe. W niektórych sytuacjach używa się częściej odpowiednika wspólnego dla hindi i urdu ${ }^{10}$, gdyż sanskrytyzm zabrzmiałby sztucznie, a w innych jest odwrotnie. Słowa pochodzenia persko-arabskiego oczywiście są powiązane z kulturą persko-islamską, a sanskryckie z tradycją hinduistyczną. W zależności od wykształcenia, pochodzenia i osobistych preferencji użytkownicy języka używają jednego lub drugiego z tych wariantów. Zatem każde słowo, pomimo zbliżonego znaczenia, ma nieco inną siatkę pojęciową, znaczenie konotacyjne, dystrybucję stylistyczną oraz frekwencję występowania (Urdang 1978, iii) ${ }^{11}$. Dzięki temu hindi-urdu dysponuje niezwykle zróżnicowanym i bogatym słownictwem.

9 O możliwości posługiwania się wyrażeniem „terytorium języka hindi” (hindī bhāṣi kṣetr) w odniesieniu do części subkontynentu indyjskiego w: Stasik 2008, 145-157.

${ }^{10}$ Niektórzy uznają istnienie pewnej mieszanki hindi-urdu („hirdu”) jako języka codziennego na subkontynencie (Kuczkiewicz-Fraś 2012, 29-30). Ze względu na różnice leksykalne na poziomie bardziej formalnym hindi i urdu stają się jednak wzajemnie niezrozumiałe (Stasik 2008, 149).

${ }^{11}$ Można też dodać m.in. znaczenie afektywne. Innymi słowy, pomimo że ich znaczenie desygnacyjne jest identyczne, nie są one tożsame funkcjonalnie, co nie pokrywa się ze znaczeniem synonimii, które poniekąd może być różnie ujmowane (Bańko 2016, 53-70). Różne synonimy mogą również być nośnikami różnych stereotypów, jak np. chłop (bardziej uparty i religijny) i rolnik (bardziej postępowy i inteligentny) (Bartmiński 2007, 79-80, 87).

Utrzymywanie podwójnego słownictwa i ogromnej ilości synonimów jest niezgodne z zasadą, 
W wypadku Vaida, który starannie dobierał swoje słownictwo i świadomie posługiwał się zapożyczeniami z urdu, budował swój styl, a nawet tym uzasadniał wybór języka, w którym tworzył, dokładne zbadanie tych wyrazów wydaje się uzasadnione. Tłumaczenie utworów Vaida bez uwzględnienia tego ważnego aspektu jego literackiego idiomu zubożyłoby i zniekształciło przekład.

W języku polskim nie ma zapożyczeń z urdu, ale znajdzie się spora grupa zapożyczeń z arabskiego czy tureckiego, dotyczą one jednak albo konkretnej dziedziny (np. militaria - buzdygan), albo pozostają w związku z dawno minioną przeszłością (np. kontusz), albo też uległy tak daleko idącym przekształceniom i wrosły w naszą codzienność tak bardzo, że nie kojarzymy początków ich użycia z tymi językami - zostały „oswojone” przez użytkowników języka polskiego (np. filiżanka) ${ }^{12}$.

Starałem się zatem znaleźć inny sposób na oddanie tej charakterystycznej cechy twórczości Vaida w tłumaczeniu, tak by odpowiednio oddziaływała na wyobraźnię polskiego czytelnika. Efekt ten osiągnąłem dzięki wykorzystaniu (w miarę możliwości) wyszukanego słownictwa, aby zgodnie z zasadą „dobrego tłumaczenia” ${ }^{13}$ wywołać u polskiego czytelnika takie skojarzenia, które mógł mieć czytelnik oryginalnego tekstu.

$\mathrm{Z}$ historii języka perskiego i urdu na terenie Indii wynikałoby, że zgodnie z pewną topologią kultury, w której kultura urdu wiąże się z konkretnymi skojarzeniami, wyszukane słownictwo urdu niesie ze sobą walory poetyckie i kojarzy się z czymś wykwintnym, z wyższych sfer, egzotycznym, ale też przebrzmiałym i anachronicznym. Jest to potwierdzone przez wielu ojczystych użytkowników języka, dla których urdu brzmi bardziej kwieciście i poetycko ${ }^{14}$. Różnica w postrzeganiu rejestrów urdu i hindi jest zatem rozpięta pomiędzy estetyką sanskrycką a perską ${ }^{15}$.

według której „Wielką rolę w ewolucji języka odgrywa tendencja, by zjawiska mowy realizowały się przy najmniejszym wysiłku” (Milewski 2004, 35). Alicja Nagórko podkreśla sprzeczność pomiędzy istnieniem synonimii absolutnej a ekonomią wysiłku (Nagórko 2004, VII).

12 Więcej na temat turcyzmów w języku polskim w: Stachowski 2007.

${ }^{13}$ Można przyjąć, skądinąd bardzo ogólnikowo, że dobry przekład to tekst „pełniący w nowym języku tę samą funkcję, jaką oryginał pełnił w swoim”, a tłumacz powinien się skupić na podobieństwie odbioru, co implikuje wyżej wymienione już podobieństwo skojarzenia. Leonard Forster, cyt. za: Nida 2009, 59. W kwestii tego, jak to podobieństwo skojarzeń uzyskać, tłumacz jest w dużej mierze skazany na swoje doświadczenie i własną intuicję.

14 "All of the above corroborates the prevailing impression that many native speakers conveyed, that Urdu has a more 'flowery' or 'poetic' language usage than Hindi” (Everaert 2010, 214).

15 „This difference can only be ascribed to the main source of divergence between Hindi and Urdu texts: the influence of their two cultural and literary heritages, of Persian-influenced aesthetics of the Urdu readership on one hand, and the Sanskrit-based Hindu aesthetics which influence 
W języku polskim wśród zapożyczeń z języków obcych galicyzmy, czyli zapożyczenia z francuskiego, są bardzo liczne. Szacuje się, że „około 13-16\% wyrazów obcego pochodzenia w polszczyźnie to wyrazy zapożyczone z języka francuskiego" (Bochnakowa 2012, XXV). Niektóre z galicyzmów funkcjonują równolegle $\mathrm{z}$ odpowiednikiem polskim, dlatego dla pewnych znaczeń mamy podwójne słownictwo, np. takie pary znaczeniowe: lingwistyka-językoznawstwo, pejzaż-krajobraz, konwersacja-rozmowa, interesujący-ciekawy, aparycja-wygląd, ambaras-komplikacja, menu-jadłospis itd. Wszystkie są znane przeciętnemu użytkownikowi języka polskiego i choć nie każdy jest świadom ich genezy, ale w niektórych sytuacjach odpowiednik francuskiego pochodzenia, chociażby ze względu na obcą strukturę, nietypową na tle wyrazów rodzimych lub dobrze przyswojonych (Svobodová 2016, 93), zabrzmi bardziej elegancko lub wyraźniej podkreśli pewną część wypowiedzi. Możliwe, że ta różnica w odbiorze lub intensywności wynika z większego wysiłku percepcyjnego i poznawczego niż w przypadku słów brzmiących bardziej znajomo lub może mieć uzasadnienie socjologiczne, gdy obcy wyraz pochodzi z obszaru, który tradycyjnie był uznawany za bardziej atrakcyjny kulturowo (Svobodová 2016, 94) ${ }^{16}$.

Skojarzenia wywołane przez galicyzmy są nieco podobne do urduizmów: język kultury, dyplomacji i przedstawiciel czasu, który po części już minął. Rzecz jasna pochodzenie, kontekst historyczny i kulturowe osadzenie tego słownictwa są inne niż w przypadku urduizmów, jest to jednak zabieg pozwalający na uwypuklenie konkretnych słów. Podobne środki stosował zapewne Vaid, świadomie czerpiąc ze źródłosłowu arabsko-perskiego. Może to być jeden ze sposobów na to, by przełożyć niestandardowy Językowy Obraz Świata (JOS) autora na równie niestandardowy albo mniej standardowy JOS w języku polskim i uzyskać tak ważne dla tłumacza podobieństwo skojarzeñ ${ }^{17}$,

present-day Hindi on the other" (Everaert 2010, 215).

16 Związki między znaczeniem etymologicznym a konotacyjnym opisane między innymi w (Brzozowska 2009).

17 Badania korpusowe również pozwalają ustalić, które słowo jest rzadziej stosowane, aby odzwierciedlić w miarę możliwości język i emocje oryginału. W przypadku języka polskiego korzystałem z wyszukiwarki korpusowej PELCRA z podkorpusem zrównoważonym. W przypadku hindi korzystałem z korpusu HindiMonoCorp oraz HindiWaC. Dla urdu z pomocą przyszedł korpus UrduCorp. Ponieważ te dwa ostatnie korpusy nie są tak bardzo rozbudowane jak Narodowy Korpus Języka Polskiego, uzupełniałem te dane zapytaniem przez wyszukiwarkę Google, aby sprawdzić, jak często dane słowo jest używane w wydaniach BBC hindi i urdu oraz „Dainik Jāgrạ”” i „Nawaiwaqt”, najstarszego dziennika urdu wydawanego w Pakistanie. Wyniki takiego zapytania nie są oczywiście idealne pod względem statystyki (Kilgarriff 2007), ale pozwalają zdobyć pewną intuicję, które słowo jest bardziej popularne. 
będąc jednocześnie nastawionym na odbiorcę jednojęzycznego i jego komfort kognitywny (Kaźmierczak 2016, 64).

Nie zawsze dysponujemy odpowiednim galicyzmem w języku polskim. Proponujemy wówczas użycie latynizmu, który również nada naszej wypowiedzi kwiecisty wydźwięk. Dlatego w moim przekładzie starałem się niektóre bardziej rzadkie urduizmy ${ }^{18}$, choć dotyczy to także - w zależności od kontekstu użycia - niektórych sanskrytyzmów, oddawać niektórymi galicyzmami.

Na przykład w opowiadaniu Cuchnąca uliczka Vaid, opisując pewną niezbyt lubianą kobietę, która terroryzuje swoich sąsiadów, używa stwierdzenia: is buṛhiyā ki śakl bahut manhūs hai / इस बुढ़िया की शक्ल बहुत मनहूस है, co można przetłumaczyć jako: „Wygląd tej staruszki jest straszny/okropny”. Występują w tym zdaniu dwa zapożyczenia z urdu: śakl (शक्ल / شكل), ,wygląd” oraz manhūs (मनहूस / منحوس), „niedobry, niepomyślny”. Co ciekawe, śakl(शक्ल) występuje tutaj zapisane zgodnie ze swoją wymową w urdu, a nie ze słownikową wymową hindi śakal (शकल) ${ }^{19}$. Badania korpusowe wykazują, że śakl rzadziej występuje w tekstach hindi niż synonimiczne rūp lub cehrā. Natomiast w tekstach urdu wyraz śakl jest stosowany częściej. Wyraz manhūs jest bardzo rzadki w hindi, ale cieszy się dużą popularnością w urdu. Natomiast użytkownicy hindi i urdu w podobnym stopniu preferują użycie przymiotnika burā. Obie te jednostki leksykalne, śakl i manhūs, stosunkowo rzadko występują w hindi, co wskazywałoby na specyfikę idiolektu Vaida. „Wygląd” proponuję zatem zastąpić w przekładzie innym rzeczownikiem, np. „aparycja”, a „zły” przymiotnikiem „odrażający”. Słowa „aparycja” i „odrażający” są znacznie mniej rozpowszechnione niż ich synonimy. Zatem zaproponowane przeze mnie tłumaczenie: „Jej aparycja jest odrażająca”, lepiej oddaje emocje oryginału.

W wyjątkowych sytuacjach ta zasada może również być rozszerzona o pewne zapożyczenia $\mathrm{z}$ angielskiego. $\mathrm{W}$ tym samym opowiadaniu narrator wyraża ubolewanie z powodu dyskomfortu, jaki spowodował u swojego rozmówcy: mujhe rañj hai ki āpkā jī micalāne lagā / मुझे रंज है कि आपका जी मिचलाने लगा. Słowo rañj (रंज / رنج) jest perskiego pochodzenia i czytelnik współczesnej literatury hindi nie napotyka tego wyrazu w tekstach oryginalnych zbyt często. Co więcej, mujhe rañj hai może również być odwołaniem do bardziej poetyckiego rejestru ${ }^{20}$. Tuż po cytowanym wyżej zdaniu autor

${ }^{18}$ Innymi słowy, te urduizmy, które znacznie odbiegają od wyżej wspomnianej wspólnej mieszanki hindi-urdu, traktujemy jako obecność języka trzeciego w przekładzie.

19 Uwagi na temat tej formy zapisu można znaleźć w: Everaert 2010, 205.

${ }^{20}$ Przykład takiego użycia znajdziemy w ghazali Iqbāla Azīma: https://www.rekhta.org/ghazals/ mujhe-apne-zabt-pe-naaz-thaa-sar-e-bazm-raat-ye-kyaa-huaa-iqbal-azeem-ghazals?lang=hi. Dostęp: 23.12.2020. 
użył pewnego rodzaju dopowiedzenia: āī em sārī (आई एम सॉरी) - to jedyny anglicyzm, który pojawia się w całym monologu. Ta zmiana rejestru nie jest przypadkowa. Kilka akapitów dalej narrator przeprosi, mówiąc muāf kījie (मुआफ़ कीजिए) zgodnie z arabską wymową, zamiast częstszego w hindi māf kījie (माफ़ कीजिए) ${ }^{21}$. Można zadać sobie pytanie, dlaczego autor używa tej niezbyt powszechnej formy wyrazu. Prawdopodobnie w jego zamierzeniu narrator ma być uznany za erudytę. Proponuję zatem przetłumaczenie zarówno zapożyczenia perskiego, jak i anglicyzmu oraz dodanie do powstałej frazy francuskiego słowa „pardon”, co uczyni wypowiedź mniej pospolitą: „Przykro mi, że się panu zrobiło niedobrze, naprawdę, przykro mi, pardon”.

Nie zawsze możemy oddać pełne znaczenie w polskim tłumaczeniu, ale warto skupić się na niuansach, np. w zdaniu: ...āp apne kaprõ kā satyānāś na kar lẽ / ... आप अपने कपड़ों का सत्यानाश न कर लें we fragmencie „żeby się panu ubrania całkiem nie poniszczyły” proponuję zamienić „ubrania” na galicyzm „garderoba”, który dużo rzadziej występuje w polszczyźnie i użycie go pozwoli odtworzyć wrażenie wyszukanego języka.

Jeśli jednak brakuje nam potrzebnego odpowiednika w konkretnym zdaniu, warto użyć go kilka słów dalej, by choć częściowo nawiązać do konotacji oryginału i oddać zamierzoną kwiecistość słownictwa. W opowiadaniu Cuchnąca uliczka narrator tak opisuje domy: śāyad ām zubān mẽ in kālī kothariyõ ko makān nahĩ kahā jātā / शायद आम ज़ुबान में इन काली कोठरियों को मकान नहीं कहा जाता, „może w zwykłym języku te ciemne klitki nie są nazywane mieszkaniami / domami”. Autor określa „język” słowem zubān (ज़ुबान / زبان), a nie bhāṣā (भाषा / بهاثـ), które częściej występuje w hindi, chociaż zubān jest powszechnie rozumiane. Trudno przenieść ten niuans na język polski, ale możemy nadrobić to w innej części zdania, zamieniając „ciemne” na latynizm „obskurne” i w ten sposób, używając rzadszego sformułowania, choć trochę lepiej oddać specyfikę oryginału. Proponuję więc taką wersję: „Może zwykły człowiek nie nazwałby tych obskurnych klitek domami”.

Czasem jednak wierne oddanie bagażu semantycznego oryginału w tłumaczeniu na polski jest niemożliwe. Na przykład w opowiadaniu Wieczór z Panną Głód występuje słowo arabskiego pochodzenia: kaifiyat (कैफ़ियत / كيفيت), które oznacza „nastawienie, sytuację”, choć synonimy hāl (हाल / حال) oraz hālat (हालत / حالت) są bardziej popularne ${ }^{22}$ we współczesnym języku, co potwierdzają badania korpusowe. Wyraz कैफ़ियत w standardowym

${ }^{21}$ Zagadnienie różnic znaczeniowych wariantów graficznych możemy znaleźć w: Bańko 2016, 58-59.

${ }^{22}$ Autor zresztą sam go używa, gdy pod koniec opowiadania stwierdza: merī hālat phir xarāb hone vālì ha „मेरी हालत फ़िर ख़राब होने वाली है”, „mój stan znowu się pogarsza”. 
hindi niemalże nie występuje, a w krótkim opowiadaniu Vaida pojawia się aż cztery razy. Problem w tym, że w języku polskim trudno znaleźć rzadszy odpowiednik słowa „nastawienie”, dlatego uzyskanie efektu zbliżonego do oryginału nie jest łatwe.

Zaproponowane przeze mnie rozwiązania mają charakter ogólny i stanowią propozycję do rozważenia w procesie przekładu wówczas, gdy urduizm (a niekiedy także sanskrytyzm) użyty przez autora jest nietypowy, nie wszedł do ogólnego użytku. Krishna Baldev Vaid często używał takich zabiegów, stosując słowa bardzo rzadko spotykane w hindi, co sprawiało, że jego dzieła były trudne w odbiorze dla przeciętnego odbiorcy. Tłumaczenie utworów Vaida bez uwzględnienia tak ważnego aspektu jego literackiego idiomu zubożyłoby i zniekształciło przekład.

Nie kwestionuję oczywiście powszechnie już stosowanych metod tłumaczeń, proponuję tylko inne podejście, które ma szansę wzbogacić warsztat pracy tłumacza z hindi-urdu na polski i przybliżyć polskiemu czytelnikowi ciekawą twórczość Krishny Baldev Vaida.

\section{एक बदबूदार गली - „Ek badbūdār galī” - Cuchnąca uliczka}

Proszę dobrze przyłożyć chusteczkę do nosa, ta uliczka jest bardzo brudna. Pewnie i chusteczka nie pomoże. Powiadają, że pewnego razu zgubiła się i przez nieuwagę zabłądziła tutaj pewna amerykańska dama. Pech chciał, że akurat nie miała przy sobie chusteczki. Biedaczka od razu zemdlała. Ale pan, niech się pan nie martwi, pan przecież jest miejscowy? No, ale na wszelki wypadek proszę trzymać chusteczkę przy nosie. O mnie proszę się nie martwić, ja należę do tej uliczki, mnie jej smród nie zaszkodzi.

Na co pan się tak patrzy, marszcząc nos? Te dwie sterty śmieci służą za bramę wejściową tej uliczki. Nie usuwa się ich, żeby nikt, choćby przez pomyłkę, nieopatrznie tu nie zaszedł. To jak ta amerykańska dama tutaj się dostała? Proszę pana, nie umiem powiedzieć. Możliwe, że ta historia nie jest prawdziwa. Ja sam czytałem o niej w jakiejś gazecie. Owszem, nawet w gazetach była już kilka razy mowa o tej uliczce.

Tak czy inaczej, proszę iść przed siebie. Pan się pewnie zastanawia, co to tam, niczym zwierzęta, kręci się po stertach śmieci przy wejściu? Proszę wybaczyć, to nie zwierzęta, to dzieciaki z tej ulicy, które całymi dniami w nich buszują. Czasami, kiedy znajdą jakiegoś zgniłego banana albo pomarańczę, albo gujawę, to podnoszą i zjadają. Na pewno pan widział, jak czasami pojawiają się ludziom koło ust takie żółtawe lub białe krosty, a przy nich ciągle bzyczą muchy. Rozumie pan, o co mi chodzi? Przykro mi, że się panu zrobiło niedobrze, naprawdę, przykro mi, pardon. 
Ależ pan wciąż się odwraca i spogląda w ich kierunku! Niech je pan zostawi w spokoju. Nic im nie będzie. Starsi ludzie mawiają, że sam Bóg opiekuje się dziećmi. Tak, tak, ja wcale nie żartuję. Jeśli pan mi nie wierzy, zatrzymajmy się tu na chwilę i zobaczy pan, że zaraz coś znajdą w tych stertach, będzie to dla nich darem niebios. Natychmiast to chapną. Zupełnie nic im nie będzie.

Co się pan tak na mnie patrzy osłupiałym wzrokiem? Proszę tam spojrzeć. Co też one zobaczyły? Rzuciły się na to wszystkie jednocześnie. Lecz jeśli ma pan wzgląd na to, co mówię, niech pan tak się nie przygląda. W przeciwnym wypadku będzie musiał się pan bronić, otoczony tymi dziećmi. Boję się, żeby się panu garderoba nie poniszczyła. Tak, tak, dobrze mówię. Jak to z dziećmi... Całymi dniami się szarpią, a potem znowu się godzą. Ale chodźmy dalej...

A oto pierwszy dom ulicy. Ale co też się pan tak dziwi? Może zwykły człowiek nie nazwałby tych obskurnych klitek domami, ale ja dla własnej wygody będę tak o nich mówił. Wszystkie domy na tej uliczce są zbudowane podobnie. A co, złe są? Przecież tak naprawdę potrzebujemy tylko dachu nad głową; w dniu ostatecznym i tak nie zabierzemy ze sobą niczego oprócz szlachetnych uczynków. Więc dom... duży czy mały, nowy czy stary, jasny czy ciemny ${ }^{23}$, jest czy w ogóle go nie ma, ostatecznie jakie to ma znaczenie? Ale proszę wybaczyć, zapędziłem się. Nie powinienem tak wygłaszać takich mądrości. To jest zadanie dla starszyzny. Tak więc oto pierwszy dom przy tej uliczce. Mieszka tu pewna wdowa o imieniu Prakaśwati, ale ludzie mówią na nią Paśo. Otóż Paśo ma dwie młode córki, Satję i Paro. Tyle że oprócz wieku nic nie świadczy o ich młodości, ponieważ wyglądem sprawiają wrażenie, jakby obie owdowiały wraz z matką. Niektórzy uważają, że gdyby nie ich matka, to już kilka razy wyszłyby za mąż. Mam nadzieję, że zrozumiał pan, co mam na myśli.

Ta Paśo to ma bardzo trudny charakter. Wszyscy mieszkańcy ulicy bardzo się jej boją. Powiadają, że lepiej jej nie podpaść. Ostatnio nieustannie z kimś się kłóci i miota ciężkimi wyzwiskami. Okłada swoje córki na środku ulicy, potem rwie sobie włosy i wybucha płaczem. Ludzie mówią, że jak Paśo rzuca przekleństwa, to zawsze się one spełniają, ponieważ jest ona bardzo nieszczęśliwa. Kilka lat temu owdowiała. Jej mąż trudnił się obwoźnym handlem warzyw, a kiedy umarł, Paśo została z niczym, nie licząc warzyw, już od kilku dni nieświeżych, i dwóch córek. Biedaczka jakoś jednak je wychowuje. Wykonuje jakieś drobne roboty i tak jakoś jest w stanie zarobić na ich utrzymanie. Tyle czasu pozostają w panieńskim stanie, ale o dziwo, jej córki nawet nie odważyłyby się na kogoś spojrzeć. Ludzie uliczki w głębi serca bardzo ją szanują za ten surowy nadzór i twardą rękę.

${ }^{23}$ W oryginale havādār ho yā ãdherā ,,हवादार हो या अँधेरा”, , ,przewiewny lub ciemny”. Porównanie zapewne spowodowane znikomą szczelnością okien w Indiach (lub ich brakiem!), których celem jest zarówno oświetlanie mieszkania, jak i zapewnianie przewiewu - wszystkie przypisy pochodzą od tłumacza. 
Ale nie wiedzieć czemu Satja i Paro cały czas się kłócą ze swoją matką. Już kilka razy doszło do bijatyk między nimi. Kiedy były małe, to Paśo zwykła je łapać za włosy i spuszczała im lanie. Ale teraz i one nie pozostają dłużne i na kopniaki odpowiadają pięścią. Paśo wciąż grozi, że wygoni je z domu, a one, że ją opuszczą. Ale kiedy gniew je opuszcza, to wszystkie trzy się obejmują i zalewają się łzami. Mieszkańcy ulicy są szczerze zadziwieni - cóż to za obyczaje!

Ale widzę, że ta historia pana nudzi i przygląda się pan tym rozdeptanym kwiatom, które leżą przed tym domem. Musi pan być zdziwiony, skąd na tej cuchnącej uliczce wzięły się kwiaty? Dziwna to sprawa, że owe kwiaty również cuchną. Poniekąd niewykluczone, że mój węch doznał szczególnego rodzaju uszczerbku na skutek ciągłego przebywania na tej uliczce. W tym domu także mieszka wdowa. Jej prawdziwego imienia nie znam, ale mieszkańcy ulicy mówią na nią, „stara jędza”. Starej całymi dniami nie ma. Niemniej wieczorem, kiedy wraca do domu, zawsze jest w towarzystwie jednej lub paru kobiet, a za nimi jeden czy dwóch mężczyzn z zasłoniętą twarzą. Kobiety mają w rękach wiązki kwiatów, których zapach miesza się z wonią z ust mężczyzn i zamienia się w ten oto smród, który przez całą noc wypełnia tę część ulicy. Następnego dnia na zewnątrz mieszkania widać te same kwiaty. Przez cały dzień plączą się pod nogami.

Mieszkańcy ulicy mówią, że dom starej jest siedliskiem wszelkiego zła. Może pan nawet czytał o tym w prasie. Ludzie kilka razy chodzili na posterunek i składali skargi. Ale od czasu kiedy mieszkańcy ulicy pewnego dnia znaleźli o poranku pewnego wysoko postawionego oficera leżącego na wznak przed jej domem, to skargi jakby ucichły. Ludzie powiadaja, że starucha ma na policji znajomości.

Jej aparycja jest odrażająca. Cały czas żuje betel24, a na jej czole zawsze widnieje tilak ${ }^{25}$. Pewnego razu, gdy drzwi mieszkania zastałem otwarte, zajrzałem do jej pokoju. Nad łóżkiem naprzeciwko drzwi wisiała podobizna Kriszny ${ }^{26}$, a obok zdjęcie jakiegoś mężczyzny, którego nie udało mi się dokładniej obejrzeć. To musiał być jej mąż.

Ludzie powiadają, że stara jest daleką kuzynką swojej sąsiadki Paśo. To możliwe, choć pomiędzy nimi trwa zacięta wojna i ludzie z całej okolicy trzymają się od tego z daleka, ponieważ staruszka ma dziwny zwyczaj polegający na tym, że podczas kłótni

${ }^{24}$ Rodzaj używki sprzedawanej na ulicy, bardzo popularnej w Indiach. Betel barwi ślinę i zęby na czerwono, a spożywany w dużych ilościach również powoduje ich wypadanie. Więcej informacji na temat tego zwyczaju w: Cielas 2016, 163-176.

${ }^{25}$ Znak na czole, przeważnie czerwony, który może mieć znaczenie religijne, świadczyć o przynależności do danej szkoły filozoficznej. Różni się od tzw. bindi, kropki między oczami, która w przypadku kobiet może oznaczać, że kobieta jest zamężna, lub mieć tylko dekoracyjne znaczenie. Ponadto bindi malowane jest tylko między oczami, podczas gdy tilak może być znacznie większy.

${ }^{26}$ Bardzo popularne w Indiach hinduistyczne bóstwo, w Bhagawadgicie opisywane jako „Najwyższa istota” lub „Najwyższy bóg”, pojawiające się w wielu dziełach filozoficznych i teologicznych. 
podciąga swoje dhoti ${ }^{27}$ i uderzając w uda oburącz, zaczyna obrzucać córki Paśo, Satję i Paro najgorszymi obelgami. Mówi wtedy: „Trzymaj ją dobrze pod ubraniem! Niech mnie szlag trafi, jeśli pewnego dnia psy cię nie przeleca!!". Wtedy Paszo zaciąga swoje biedne córki do domu i głośno zawodzi, prosząc Boga o śmierć dla starej wiedźmy.

Mieszkańcy uliczki mają ciężko ze staruszką. Starucha ogłasza wszem i wobec, że jeśli komukolwiek ciężko z pieniędzmi, zawsze może posłać do niej na noc, na kilka godzin, córkę albo synową. Według mieszkańców niektórzy bezwstydnicy ukradkiem korzystają z tej propozycji.

Zwłaszcza mieszkająca naprzeciwko Phulo. Ludzie już kilka razy na własne oczy widzieli, jak wchodziła do mieszkania staruchy. Kilka razy słyszano nawet, że mąż skarżył się na jej bezwstydne zachowanie, ale biedak niewiele może zrobić, ponieważ już od dłuższego czasu leży chory. Mówi, że gdyby nie choroba, nigdy by nie pozwolił, żeby za jego życia tak brukała jego honor. Zanim zachorował, pracował jako rikszarz rowerowy. Ta rozklekotana riksza, która stoi przed domem, należy właśnie do niego. Nawet teraz mawia, że jeśli odzyska siły i tej ladacznicy nie wyrzuci z domu, to nie nazywa się Ramdajal. Czego to ludzie nie mówią w złości... Ale wie pan, bez lekarstw jeszcze nikt nie wyzdrowiał. Biedny Ramdajal jedynie na pocieszenie snuje marzenia o powrocie do zdrowia i wygnaniu Phulo z domu.

Od pewnego czasu brzuch Phulo zaczął puchnąć. Wszyscy wiedzą, że to nie jest dziecko Ramdajala. Sam Ramdajal, prowokowany, oznajmia wszem i wobec, że nie jest ojcem tego bękarta. Ale zdziwi się pan, że to Phulo, grożąc mu butem²8, mówi, aby uważał na swoje słowa. „Nie jesteś jego ojcem, zgoda, ale ja jestem jego matką”. Sam pan może sobie wyobrazić, jak on się wtedy czuje. Kilka dni temu próbował nawet udusić się za pomocą sznurka ze swojego ćarpaja29, ale Phulo akurat była w domu i to zobaczyła. Wykrzykiwała, ściągając przed dom całą ulicę. Zamiast poluzować mu węzeł na gardle, powtarzała: Gdybym tego nie zauważyła, to przecież mnie ludzie by za wszystko obwiniali!". Wtedy ktoś ze zgromadzonych wystąpił z tłumu i oswobodził Ramdajala, a ten, jak tylko stanął na nogi, począł krzyczeć boleśnie: Ludzie! Albo mnie zabijcie, albo zabierzcie ją stąd!".

Ale w tłumie znalazło się kilku rozsądnych ludzi. Tłumaczyli mu: „Nie bądź głupi, jeśli będziesz ją denerwował, to stracisz nawet te dwa placki30, które codziennie dostajesz. Uspokój się, o co ci chodzi? To o niej ludzie będą źle mówić".

Po tym, z niewiadomych powodów, Ramdajal wybuchnął płaczem.

${ }^{27}$ Tradycyjny strój, przeważnie męski, składający się z jednego kawałka materiału upiętego w pasie.

${ }^{28}$ Bardzo obraźliwy rodzaj zniewagi w Indiach, gdzie obuwie uważane jest za szczególnie nieczyste.

${ }^{29}$ Rodzaj łóżka lub leżanki zrobionej ze sznurków splecionych na drewnianej ramie.

${ }^{30} \mathrm{~W}$ oryginale rotī, rodzaj pieczywa, placki z mąki razowej smażone bez tłuszczu. W Indiach jedno z najtańszych pożywień. 
Pan teraz pewnie myśli, że i ja muszę być zepsuty, skoro tak opowiadam o tych paskudnych sprawach. Ale co poradzę, tak długo już tu mieszkam... Dziś po raz pierwszy mam szansę otwarcie porozmawiać, więc proszę się uzbroić w cierpliwość i słuchać, to będzie mi lżej na sercu, a przy okazji może i lżejszy będzie smród cieczy, która płynie w moich żyłach.

Sprawia pan wrażenie nieco znudzonego. Chodźmy dalej, przyśpieszymy trochę. Zresztą, w tej części uliczki jest tyle dymu, że nie można się zatrzymywać. Dusić by się pan zaczął. Tak naprawdę, są tu domy garncarzy, w których znajdują się małe piece. I to z nich unosi się ten dym. Wyrabiają oni małe czarki do herbaty, kubki i ustniki do fajek wodnych. Te osły należą właśnie do nich. Zresztą oni sami wiecznie są tak umorusani ziemią i sadzą, że wyglądają jak osły.

Idąc tak, proszę rzucić okiem na szewca siedzącego przed nami. Możliwe, że tak dziwnego szewca pan nigdy nie widział. Od iluż lat tutaj siedzi! I zawsze jest tak pochylony nad swoją pracą, więc wyrósł mu na plecach garb jak u wielbłąda. Od czasu do czasu jakieś gamonie, widząc go tak zaabsorbowanego pracą, klepią go po plecach. Latem, kiedy siedzi czasem rozebrany do pasa, jego kręgosłup napawa strachem. Nie wiadomo, jak to się stało, że jeszcze nie przebił mu pleców na wylot.

Mieszkańcy uliczki powiadają, że szewc jest wariatem. Możliwe, że jest to prawda, bo mało dostaje butów do naprawy, a jednak cały czas coś robi. Od czasu do czasu przeżuwa jakąś podeszwę z rozprutych, leżących przy nim butów, tak jakby jadł roti. Ale potem nagle sobie zdaje sprawę, że zamiast roti żuje suchy szorstki kawałek skóry. Wyciąga go wtedy z ust, zaczyna pluć przeżutymi kawałkami i podrzucając je w górę, ku niebu, krzyczy: „Sam ${ }^{31}$ sobie jedz, sam!”.

A teraz, jeśli pan sobie życzy, możemy się tu zatrzymać na chwilę. Tutaj też jest zadymione, ale trochę mniej. Bardzo proszę się odwrócić w tę stronę. Z tamtej dwie kobiety właśnie oddają mocz. Tak, bezwstydne, ale co począć? Jak nie na ulicy, to gdzie mają to robić? W kuchni? Tak jest, proszę pana, na tej ulicy żaden z domów nie ma osobnego pomieszczenia czy to za dużą, czy małą potrzebą. Przynajmniej na to wygląda, bo jak widać obydwie sprawy załatwiane są w każdym zakamarku ulicy.

W domu naprzeciwko mieszka para staruszków. Dziadek ma pewnie z siedemdziesiąt lat, staruszka siedemdziesiąt pięć. On już prawie nic nie widzi, a do niej trzeba tak głośno mówić, że można powiedzieć - nic nie słyszy. Dziadek nie postawi ani kroku, póki dokładnie nie wybada drogi za pomocą laski, a ona w ogóle nie może chodzić. Do niedawna jeszcze mogła się przemieszczać na czworakach. Dziadek sprzedaje orzeszki, siedząc przed drzwiami swojego domu. Nie uwierzy pan, ale pomimo ślepoty

${ }^{31}$ Pojawia się tutaj zaimek osobowy tū, oznaczający tak samo pogardę, jak i dużą bliskość i spoufalenie, na przykład w czasie modlitwy do boga. W tym wypadku sytuacja tym bardziej dwuznaczna, że protagonista pluje kawałkami podeszwy, która w kulturze indyjskiej kojarzy się z nieczystością jako część ubrania stykająca się z brudem ulicznym; ponadto buty wykonane są ze skóry zwierzęcej - jeszcze jedna nieczysta rzecz. 
potrafi po omacku rozróżnić prawdziwe monety od podrobionych. Jak można oszukać na orzeszkach za kilka pajsów32? Ale i tak każdą monetę dokładnie bada i obstukuje, a cały dzień jęcząca staruszka leży obok na ćarpaju. Wieczorem ktoś z uliczki przynosi im z targu dwa placki roti oraz gotowaną soczewicę. Dziadek dzieli roti na kawałki i miesza z soczewicą. Trochę je sam, a trochę wsadza babci do ust. Staruszka, jedząc, płacze jak dziecko, a dziadek, rzucając przekleństwami, zabrania jej płakać i poucza, że powinna dziękować Bogu. Ale staruszka zamiast składać dziękczynienia, woła swojego syna, Ramlala, i skarży się, że odchodząc, nie zabrał jej ze sobą.

Czasami dziadek się zdenerwuje, wyrzuci miskę z soczewicą na środek ulicy i jakiś pies przybłęda zaczyna ją lizać.

Och, widzę, że zrobiło się panu niedobrze. Chodźmy dalej. Te kobiety już sobie poszły.

W tym domu mieszka pewien woźnica, Basati, prawdziwy despota. Cała ulica się go boi. Wygląda imponująco, a głos ma przerażający. Jak bije swoją żonę, Dhaniję, ludzie są bardzo poruszeni. Za każdym razem wydaje się, że tym razem ją zabije. Bije do nieprzytomności, chwyta za włosy i zaciąga na ulicę, a kiedy ona pada nieprzytomna, zamyka drzwi od środka, mówiąc: "Nie waż mi się wracać do domu”.

I co ja mam panu jeszcze powiedzieć? Ta kobieta ma tak twarde kości, że nawet po takim laniu nic jej nie jest. Zostaje całą noc na zewnątrz, a o poranku, kiedy Basati wyjedzie wozem do pracy, wstaje i wraca do domu, gdzie przez cały dzień odgrywa się na dzieciach.

Tak, pewnego razu próbowałem przemówić do rozumu Basatiemu. Powiedziałem mu: „Popatrz, ale jeśli kiedyś ona umrze, to co się stanie z dziećmi? Jak je wychowasz, przecież są jeszcze małe?". Tak w ogóle Basati to bardzo towarzyski człowiek., Babudźi³, co ja ci mogę powiedzieć, jeśli umrze, to tym lepiej", odpowiedział. Wtedy nie zrozumiałem, o co chodzi, ale potem dowiedziałem się, że te dzieci Basati miał ze swoją pierwszą żoną i jeśli tak bije Dhaniję, to dlatego, że ona nie traktuje ich dobrze.

Tak czy inaczej, nie rozumiem do końca jego okrucieństwa. Niektórzy mówią, że ma on wątpliwości, czy Dhanija czasami nie chodzi wieczorami do mieszkania starej jędzy. Nic nie mogę na ten temat powiedzieć, ponieważ nie mam odwagi zapytać o to Basatiego.

Ale wydaje mi się, że nie słuchał pan historii o Basatim zbyt uważnie, bo inaczej na pewno by coś pan powiedział. Co pan mówi! Pan chce już wracać? Proszę zaczekać, nie wstąpi pan do mnie do domu? To jest tu, naprzeciwko.

Dobrze, nic nie szkodzi. Ale i tak niech pan zaczeka. W tym domu wydarzyło się ostatnio coś dziwnego, niech pan tego posłucha. Dom jest dosyć duży i tak naprawdę mieszkają tu trzy rodziny. Tak, z zewnątrz nie wydaje się szczególnie duży, ale w środku są cztery pokoje, trzy na dole i jeden na górze. Ja mieszkam na górze. Tak proszę pana,

${ }^{32}$ Najmniejsza jednostka monetarna w Indiach, dzisiaj już niestosowana. 100 pajsów = 1 rupia.

${ }^{33}$ Uprzejma i pełna szacunku forma zwracania się do mężczyzny. 
ale co poradzę, ciężko jest znaleźć mieszkanie za pięć rupii miesięcznie na innej ulicy. Pomyślałem sobie, że i tak jestem sam, a pokój jest nieco oddalony od samej ulicy. Zresztą, nieważne. Co poradzić, za naukę trzeba płacić, a i ze dwadzieścia, dwadzieścia kilka trzeba posłać co miesiąc do domu. Nie, proszę pana, żony nie mam, ale rodziców, owszem, tak.

Zresztą rozmowę o mnie odłóżmy. Tak więc w tym domu mieszkają trzy rodziny. Tak naprawdę jest to jedna rodzina, ale podzielona na trzy. W jednym pokoju mieszka małżeństwo z dwójką dzieci. Siostra kobiety z pierwszego pokoju mieszka ze swoimi dziećmi w drugim. Mąż zostawił ją i gdzieś odszedł - tak niektórzy twierdzą. Zaginiony od lat, nie wiadomo nawet, czy żyje. A w trzecim pokoju - ojciec tych dwóch sióstr wraz z ich macochą.

Mają dwójkę dzieci, dwie córki. Jedna ma siedem, a druga dziewięć lat. Mieli też młodego syna, ale popełnił samobójstwo.

Panu się spieszy, inaczej bym opowiedział wszystko, co mieszkańcy tego domu robią, co jedzą, co piją i tak dalej. Co najistotniejsze, te trzy rodziny są bez grosza, dokładnie jak pozostałe, które mieszkają na tej uliczce.

Tak, obydwie siostry walczą ze swoją macochą, ale między sobą też się kłócą. Co się tyczy dzieci, nie wiem dokładnie, które jest czyje. Biedactwa żyją w ciągłym strachu z powodu tej sytuacji. Moim zdaniem z całej ulicy to są najbardziej nieszczęśliwe dzieci. Widać, jak po ich twarzach krąży widmo śmierci.

Ale koniec końców, ja chciałem opowiedzieć o ojcu tych sióstr, który trzy razy się ożenił. Obydwie siostry są z jego pierwszego małżeństwa. Z drugiego nie miałżadnych dzieci, a z trzecią żoną, tą obecną, ma dwie córki. Był też i syn, ten, co już nie żyje.

Zmarł, zanim tu zamieszkałem, ale słyszałem, że jego śmierć pogrążyła ojca w takiej żałobie, że najpierw stracił wzrok, potem słuch, a potem nagle przestał mówić. Kilka miesięcy temu, kiedy go zobaczyłem, to biedak nic nie widział, nic nie słyszał i nie mógł mówić. Możliwe też, że była to jakaś choroba.

Ale dziwne jest to, że nagle zaczął być wiecznie głodny. Jego żona, Lakszmi34, cały czas się na to uskarża. Na samym początku nie wierzyłem, ale pewnego razu sam zobaczyłem, jak pochłonął przy mnie dwadzieścia roti, jedno po drugim. Z czasem zasłynął tym apetytem na całej ulicy. Od rana do wieczora na dziedzińcu tego domu odbywało się coś na kształt przedstawienia. Siedział, ludzie rzucali mu roti, a on niestrudzenie podnosił je do ust i pochłaniał. A kiedy kończył jeść, wyciągał rękę i jęcząc "aaa, aaa", prosił o więcej.

Lakszmi pyta:„Ludzie, co ja mam zrobić?", a obie pasierbice drażnią ją, mówiąc:„Przez całe życie cię żywił, a teraz, jak jemu trzeba dać jeść, to się skarżysz? Rób, co do ciebie należy, i już". Ciekawe jest przy tym to, że obydwie córki nie miały dla swojego ojca

${ }^{34}$ W hinduizmie Lakszmi jest boginią szczęścia, bogactwa i piękna. Uosabia wszelkie powodzenie - może wybór takiego imienia jest objawem ironii autora? 
żadnego współczucia. Lakszmi, rozsierdzona tymi docinkami, mówiła: „Mam napełniać piekielny brzuch tego starego wołu czy żywić te dwie niewinne dziewczynki? Co ja mam zrobić? Z czego mam płacić? Jak nic mu nie daję, cały czas się domaga! Jakie złe duchy go opanowały? Ludzie...! Gdzie ja mam pójść, powiedzcie mi...!".

I za każdym razem gdy przemawiała tak do cierpliwie stojących ludzi, starzec wyciągał ręce i dziwacznym nieludzkim głosem prosił o roti.

Aż w końcu pewnego dnia... to jest jeszcze świeża sprawa... Lakszmi wzięła staruszka za rękę i gdzieś go zabrała, a gdy już wróciła, była sama. Nie wiadomo, gdzie on teraz jest. Ludzie powiadają, że Lakszmi go zostawiła na moście z żebrakami, koło dworca głównego. Obydwie pasierbice całymi dniami ją męczą swoimi docinkami, a ona nie pozostaje dłużna. Dzieci są jeszcze bardziej zastraszone. Słyszę, że ze strachu nie proszą o więcej niż jedno roti.

A teraz jeśli pan chce, może zawrócić, wciąż zakrywając nos chusteczką. To był ostatni dom uliczki. Kiedy smrodu już nie będzie, może pan uznać, że to koniec uliczki.

\section{भूख कुमारी के साथ एक शाम - „Bhūkh kumārī ke sāth ek shām” - Wieczór z Panną Głód}

Odbywałem wieczorny spacer po ulubionej uliczce. Szedłem powolnym krokiem, z głową wolną od zmartwień. Oddychałem głęboko, próbując się wyciszyć, i uśmiechałem się do siebie, widząc, jak bezskuteczne są te próby. Noc jeszcze nie rozpuściła całkiem swoich włosów. Z jednej strony niebo jarzyło się pomarańczową barwą, która z każdą kolejną chwilą przygasała, podobnie mój uśmiech. Ulica rozciągała się przede mną jak zmiażdżony wąż, a ja niczym bezdomny starzec bezlitośnie deptałem i jego, i samego siebie. Nie dotarłem jeszcze do tej skały, na której każdego wieczoru, przybrawszy pozę myśliciela, siadam i wpatruję się w mrugające w oddali światła slumsów. Czasem na tej skale rozkładam ręce, wpatruję się w te slumsy, a moja wyobraźnia trzepoce jak krążące wokół nich gołębie. Nieraz już, gdy tak stałem na tej skale z rozłożonymi rękoma, nachodziła mnie myśl, by skoczyć w sieć tych slumsów. Taka myśl nawiedza mnie właściwie za każdym razem, gdy stoję gdzieś wysoko, ale nie pozostaje ona ze mną na dłużej ani nie powoduje drżenia ciała. Nadałem jej miano myśli martwo urodzonej. Nie dochodzę dalej niż do tej skały. Każdy stary, szanujący się spacerowicz ma jakieś drzewo, kamień, zakręt, rów lub jakikolwiek znak orientacyjny, poza który nie wychodzi, choć chciałby wyjść. Tego wieczoru również nie poszedłbym dalej niż ta skała, ale wydało mi się, że ktoś tam siedzi. I wcale nie przyszło mi do głowy, żeby usiąść obok tej osoby. Gdybym ją zobaczył z daleka, łatwiej byłoby mi zapanować nad sytuacją, ale ponieważ szedłem z opuszczoną głową i dopiero w pobliżu skały zauważyłem, że moje miejsce jest zajęte, nie uznałem za stosowne, by stamtąd zawrócić. Gdybym teraz 
zawrócił, byłoby to niezręczne. Nie przyjrzałem się dobrze rozmazanemu lekko cieniowi siedzącemu na skale. To także wydawało mi się niestosowne. Tkwi w moim umyśle taki czujny cenzor. Każdego wieczoru uśmiecham się do siebie, bezskutecznie próbując go usunąć i wyciągnąć na zewnątrz. Zatrzymałem się na chwilę przy skale i poszedłem dalej. Pomyślałem, że zrobię jeszcze kilka kroków przed siebie, a potem spojrzę w bok pod jakimś pretekstem i sprawdzę, czy ktoś tam jest, czy nie, a potem szybko zawrócę, jakbym sobie nagle o czymś przypomniał. Ale gdy tylko zrobiłem dwa kroki naprzód, wychodząc poza skałę, moje nastawienie zmieniło się i już nie miałem ochoty odwrócić się i spojrzeć za siebie. Po kilku kolejnych krokach podniosłem głowę, mój chód stał się żwawszy, rozbiegane oczy zaczęły spoglądać na otoczenie i niespodziewanie przestałem się dręczyć. Nowy uśmiech rozkwitł na moich ustach i poczułem się tak, jakby za skałą zaczynał się nowy świat. Tak, byłem zaskoczony, ale nie pozwoliłem, by stan ten trwał długo. Bałem się, że zacznę się bać. Zerwał się wiatr, a wraz z nim przyszło pewne poruszenie, więc wyciągnąłem szyję i zamaszyście wymachując rękami, ruszyłem żwawym krokiem, niczym oficer wojska lub członek Arjasamadż35. Poruszam się żwawo jak na swój wiek, ale wieczorem na mojej ulubionej ulicy idę raczej niemrawo, ponieważ nie spaceruję w trosce o tężyznę fizyczną, lecz dla zgłębienia tajemnic własnej duszy i oczyszczenia umysłu. Inna sprawa, że zamiast zgłębiać własną duszę, zaczynam ją rozdeptywać i myślę sobie, że to też może jest jakąś nieodzowną częścią introspekcji. Jeszcze inną kwestią jest to, że choć umysł pustoszeje, to pomimo tego wcale nie staje się czysty.

Ale to odczucie również nie towarzyszyło mi zbyt długo. Nagle poczułem, jakby ktoś za mną szedł. Często mam takie wrażenie, szczególnie na opustoszałych uliczkach wieczorową porą, kiedy dzień powoli dogorywa. I to wrażenie całkowicie mnie przeraża i staję się czujny. Co prawda mam ochotę się odwrócić, ale brakuje mi odwagi. Najczęściej to złudzenie po jakimś czasie mija samo jak napad padaczki. Ale potem długo jestem w takim napięciu, zaabsorbowany czekam na to, aż idący o krok za mną potwór rzuci się, by mnie udusić. Nigdy to nie nastąpiło, ale to nie oznacza, że nie może się kiedyś zdarzyć. Również i tego wieczoru moje ciało było gotowe na nagły i śmiertelny atak. Nie wiadomo, czy przyspieszyłem, czy też spowolniłem krok. Odgłosy stąpającej za mną istoty coraz wyraźniej dobiegały do moich nasłuchujących uszu. Chęć odwrócenia się przegrała z moim dawnym lękiem - co zrobię, jeśli za mną nikogo, niczego nie ma? Osoba czy też zjawa, która za mną szła, była bosa i zbliżała się do mnie tak szybko, jakby biegła. Nigdy przedtem nie miałem takiego wrażenia, że coś za mną biegnie. Spanikowałem i wydawało mi się, że też i ja zacząłem bezwiednie

35 Ārya-Samāj, „Towarzystwo aryjskie”, założona w 1875 reformatorska i fundamentalistyczna organizacja hinduistyczna, głosząca wyższość cywilizacji indyjskiej i stawiająca ją za wzór dla całej ludzkości. Początkowo celem Arjasamadź była odnowa religii hinduistycznej i ograniczenie zachodnich wpływów, w tym islamu i chrześcijaństwa, na terenie Indii oraz walka o niepodległość. Z czasem stał się organizacją nacjonalistyczną i paramilitarną (Stępień 2014). 
biec. Ale nie, ja nie biegłem. Czekałem, aż te moje halucynacje mnie opuszczą. Często, gdy moje ciało jest już całkiem zlane potem, to idące za mną odgłosy kroków nagle milkną i wtedy wiem, że kryzys minął. Ale tego wieczoru moje ciało było zupełnie suche, a odgłosy kroków, człap-człap-człap, były już bardzo blisko mnie. Zacząłem się niepokoić, że dzisiaj naprawdę ktoś za mną biegnie. Wtedy dotarł do mnie figlarny głosik: „No, niech się pan odwróci i spojrzy na mnie!”. Nie zdziwiłem się. Był to głos małej dziewczynki. Rozbrzmiewała w nim pewność siebie, a w tej figlarności kryła się delikatność. Lęk mnie opuścił. Zatrzymałem się. Ona również przystanęła. Stałem przez chwilę w nadziei, że mnie wyprzedzi, zagrodzi mi drogę i stanie przede mną. Pomyślałem, że to pewnie ona siedziała na skale. Ale nie stanęła przede mną ani też więcej się nie odezwała. Wtedy zrozumiałem, że nie odpuści i dopóki to ja się nie odwrócę i na nią nie spojrzę, będzie dalej milczeć. Pomimo młodego wieku była uparta. Nie odebrałem źle jej uporu.

Uśmiechała się. Stała boso, bez nakrycia głowy. Miała na sobie niebieską spódnicę, brudną po kolana, a w kępie kudłatych włosów czerwoną kokardę. Czerwienią mienił się też jej uśmiech, choć same usta były suche, a na policzkach rysowały się smugi brudu. Dłonie trzymała za głową, miała szczupłe nadgarstki. Wystawały jej niewielkie, spiczaste piersi. Z jej ogromnych oczu emanował blask. Pomyślałem, że to z powodu tego blasku tak dobrze było ją widać w ciemności. Opuściły mnie wszelkie obawy. Kim jesteś? - zapytałem łagodnym głosem.

Usłyszałem cicho wypowiedziane imię, które jednocześnie mnie zdziwiło, wywołało lekki uśmiech i delikatny ból. - Panna Grób! Cóż to za imię? - Panna Grób! Niesamowite! - powtórzyła ze śmiechem.

Miałem wrażenie, że to wieczór się śmieje. Ale zrozumiałem, że jestem w błędzie, że to mnie udzielił się jej śmiech. A jej musiało się wydawać, że śmieje się noc. - Nie Panna Grób, tylko Panna Głód ${ }^{36}$ - odparła.

Przestałem się śmiać i pogrążyłem się w myślach. Nie były one zbyt klarowne, ale też nie wypadało mi długo milczeć, więc odezwałem się: - Cóż za niezwykłe imię!

Na co ona natychmiast odpowiedziała: - A co, mój wygląd nie jest niezwykły?

Byłem pod wrażeniem. Dziewczynka była inteligentna, ale nie powinna się włóczyć o zmroku, z dala od ludzi. Odprowadzę ją do domu. Aby podtrzymać rozmowę, rzekłem: - Nie, nie wyglądasz dziwnie. - Ja dobrze wiem, kim pan jest, gdzie pan mieszka, co robi... - odparła na to, a jej przerwałem: - Naprawdę? - Słowo honoru!

Naszedł mnie śmiech, a być może i myśl, że dziewczynka jest niebezpieczna. Odsuwając myśl o zagrożeniu na bok, zapytałem: - Co tutaj robisz? - Rozmawiam z panem.

${ }^{36}$ W oryginale Bhūkh kī mārī, „zabita głodem, zabita od głodu”, i Bhūkh kumārīi, „Księżniczka Głód” lub „Panna, młoda dziewczyna”. W dewanagari nie ma podziału na małe i duże litery, pisząc więc imię bohaterki od dużej litery, wprowadzamy pewną alegoryzację, której nie ma $\mathrm{w}$ oryginale. 
Tym razem jej śmiech mnie speszył. Natychmiast przypomniałem sobie, ile mam lat. Ta dziewczynka robiła sobie ze mnie żarty. Spojrzałem na nią srogim wzrokiem i surowym głosem spytałem: - Gdzie mieszkasz? - Tam na dole, w tych slumsach odpowiedziała. - To co robisz tu na górze? - spytałem, ryzykując, że odpowie mi tak jak za pierwszym razem. - Spaceruję - odparła.

Poczułem złość. Wytłumaczyłem sobie, że nie ma sensu się denerwować, trzeba dać coś biedaczce na odczepnego i ją odprawić. - Czego potrzebujesz? - Niczego.

Zauważyłem wtedy, że szliśmy obok siebie, trochę tak jakby była moją córką. Znowu się rozczuliłem. Skała była teraz wolna. Gdyby nie było ze mną tej dziewczynki, to może dzisiaj poszedłbym bardzo daleko i bardzo późno wrócił. Może dziewczynkę wysłano właśnie po to, żeby mnie zawrócić. Miałem ochotę powiedzieć: „Schodź już tam na dół, ja muszę iść dalej". Ale nie musiałem nigdzie iść. Zresztą już mi się nie chciało. Kiedy indziej, innego wieczoru, pomyślałem. Doszliśmy do skały. Zatrzymałem się. Ona też się zatrzymała. - Co robiłaś na skale? - spytałem. - Czekałam na pana. - Dlaczego? Chcę o czymś z panem porozmawiać. - Mów. - Najpierw usiądźmy na skale - odparła.

Ledwie usiedliśmy na skale, a znów naszła mnie myśl, by skoczyć w dół, w te migocące slumsy. Wydawało mi się, że ta dziewczynka skradała moje myśli. Siedząc tuż naprzeciwko mnie, badała mnie swymi wielkimi połyskującymi oczyma. Żeby tylko nie była wariatką. Panna Głód! Pewnie sama tak się nazwała. Na myśl o tym imieniu dopadł mnie gorzki śmiech. Jej głos podobny był do głosu tych księżniczek z filmów. To przecież pewne, że oglądała filmy. W każdym slumsie jest kolorowy telewizor. I lodówka. A może nawet i magnetowid. Zastanowiłem się. Pewnie żebrze, śpiewając piosenki. Nie, na pewno nie żebrze. Obydwa kolana miała obtarte. Jej szyja była tak chuda, że można by ją objąć choćby nawet drobną dłonią. Może to z głodu jej oczy tak połyskiwały. Przyszło mi na myśl, żeby przytrzymać dłonią jej głowę i poprawić kokardę. - Od ilu dni nie jadłaś? - spytałem. Patrzyła na mnie bez mrugnięcia. - Oglądasz telewizję? - Czasami. - Masz w domu telewizor? - Nie.

Zdałem sobie sprawę, że zadaję nie takie pytania, jakie powinienem zadawać. Takie, jak u niektórych pisarzy zadają protagoniści, gdy idą do kurtyzan, tylko po to, żeby sobie pokonwersować. Postanowiłem, że teraz już o nic nie będę pytał. Nie wiem, co ona chce mi powiedzieć. Wszystko o mnie wie. Pewnie także i to, przez jak trudny okres teraz przechodzę. Myśląc o tych komplikacjach, doznałem olśnienia. Biedaczka o niczym nie wie. Panna Głód! A gdyby przypadkiem była wróżką? W dzieciństwie nigdy nie widziałem żadnej wróżki, to tym bardziej na starość...

Dawno już wieczór rozpuścił swoje włosy. Niebo jarzyło się całą masą migotliwych punkcików, a pomarańczowa zorza już zupełnie zniknęła. Była głucha noc. Ja po prostu siedziałem jak stary, zagubiony maharadża, któremu jakaś dziewczyna trudniąca się zbieraniem drwa opowiada niestworzone historie. Oczy Panny Głód błyszczały. Jej nagie stopy wyglądały jak dwie małe uśpione ptaszyny, oddzielone od jej szczupłych 
nóg. - Panno Głód, proszę jeszcze coś powiedzieć. - Poczekajmy, aż się całkiem ściemni. Gdzie się pan spieszy? Przecież jest pan dzisiaj sam.

Stałem się czujny. Czyżby ona mnie szpiegowała?! - Owszem, jestem sam, ale i tak muszę wracać do domu.

Natychmiast chciałem cofnąć te słowa. Poczułem się zawstydzony, że mam dom, w którym mogę się schronić. - Przecież to jeszcze nie czas na pański codzienny rytuał - odpowiedziała.

Naprawdę wszystko wiedziała. Musiała osobiście znać moją pomoc domową. Pewnie ona też mieszka w tutejszym slumsie. Nagle dopadła mnie uporczywa myśl, żeby pójść z nią do jej domu. Ale nic nie wspomnę o tym. Jeszcze by się wystraszyła. A poza tym - pójdę i co dalej? Mogę to sobie wyobrazić. Śmieci mi nie brakuje wokół własnego domu. Pod tym względem nasz kraj przoduje. Dzielnica bogata czy biedna, brud prawie wszędzie taki sam. - Owszem, jeszcze nie pora, ale od czasu do czasu robię sobie przerwę. - Naprawdę? - Słowo honoru!

Roześmialiśmy się równocześnie. Po chwili rzekła: - Ma pan przyjemny śmiech.

Nie byłem gotów na takie komplementy z jej strony. Zmieszałem się. Nie mogłem odgadnąć, co siedzi w jej głowie. Powinienem był coś powiedzieć, ale milczałem. - Pan każdego wieczoru tu siada i przez jakiś czas patrzy w dół na migoczące w oddali slumsy.

A teraz pewnie mi jeszcze powie, że każdego wieczoru rozmyślam, czy w te slumsy nie skoczyć. - Z twojego domu widać tę skałę? - spytałem.

Nie odpowiedziała od razu, ale potem szelmowskim głosem rzekła: - Z mojego domu widać cały świat. - Nie wiem dlaczego, ale przeraziła mnie ta odpowiedź. Nie byłem gotów na takie wywody. - Czemu pan dzisiaj poszedł dalej? - zapytała. - Bo moje miejsce było zajęte. - Zobaczył mnie pan? - Ciebie akurat nie zobaczyłem, ale zauważyłem, że moje miejsce nie jest wolne. - Ale pana miejsce wcale nie było zajęte. Przecież ja siedziałam dokładnie tu, gdzie siedzę teraz. - Ale ja uważam, że moje miejsce to cała skała - stwierdziłem.

Myślałem, że się roześmieje lub zrobi coś takiego, co mnie rozbawi, ale ona pogrążyła się w myślach o czymś zupełnie innym.

Pierwszy raz miałem sposobność siedzieć na skale i w takich okolicznościach, w taki sposób rozmawiać z nieznanym mi, błyskotliwym dzieckiem. Co ona chce mi powiedzieć? Czego się obawia? Muszę jej pomóc. Powiedzieć coś, dzięki czemu łatwiej będzie jej mówić. Może ktoś u niej w domu jest chory. Albo dopadło ją jakieś inne nieszczęście. Nagle zrozumiałem, jak bardzo małostkowe są te domysły, i chcąc to stłumić spytałem: - Chodzisz do szkoły? - Chodziłam, teraz już nie. - Czemu przestałaś? - Nie miałam ochoty. - Dlaczego? - To, czego tam uczyli, dobrze już znałam. Mam bystry umysł.

Buzię miała tak poważną, że aż się zaśmiałem. Ale ona nie odpowiedziała tym samym. - Pan nie wierzy. 
Aż podskoczyłem. Czyli zna nawet ten mój defekt. - W co? - zapytałem, znów pozorując opanowanie.

Bałem się, że odpowie, że we wszystko, ale mnie oszczędziła: - W to, co mówię.

Odetchnąłem z ulgą i odrzekłem z czułością: - Ależ wierzę... - Dziwi to pana? - przerwała.

Nazwać zdziwieniem to, co odczuwałem pod wpływem jej słów, nie było trafne, ale nie chciałem w to brnąć. Milczałem. To, co mówiła, sprawiało mi radość, jak ograniczonemu, staremu, bohaterowi powieści, który rozmawia z innym bohaterem tejże powieści, niezależnym, młodym wiekiem, ale dojrzałym umysłowo. Zapragnąłem powiedzieć jej, żeby spotykała się ze mną codziennie koło tej skały. Po krótkim spacerze też siadywalibyśmy tutaj i tak debatowali o ważnych sprawach. Ale nie powiedziałem tego. Wydawało mi się to nieodpowiednie. Bałem się, że się spłoszy, zada jakieś pytanie albo powie coś takiego, co mnie przybije. Postanowiłem sobie, że będę zachowywał się naturalnie, mniej mówił, więcej słuchał. Istniało ryzyko, że jedna nieodpowiednia uwaga, jedno pytanie, jeden ruch mogą zaburzyć tę delikatną równowagę między nami. Ale przesadne rozmyślanie też może zagrozić spontaniczności. Ja byłem spięty, a ona, ukontentowana, niczym księżniczka, była sobą. Na myśl o jej imieniu znów zaśmiałem się w duchu. Z pewnością rodzice jej tak nie nazwali. Sama musiała je sobie nadać. Przeszło mi przez myśl, żeby ją zapytać o rodziców, ale to raczej byłoby nie na miejscu. Co powiem, co zrobię, jeśli oznajmi, że ich nie ma? Poczułem, że stwarzam sztuczne problemy. Mrok tych myśli wpędził mnie w złość. Zrobiło się już zupełnie ciemno. Na ulicy nie było ani jednego światła. Żółty księżyc błyszczał z jednej strony, gwiazdy z drugiej, jakby osobno. Wielkie oczy Panny Głód lśniły w ciemności. Takie duże oczy mają tylko głodujące dzieci. Możliwe, że biedaczka od rana nic nie jadła. Jej ciemne nadgarstki wydawały się jak ze szkła, ale jej nogi wyglądały niczym dwa zdrowe ptaki. Albo raczej dwa skrzydła. Moje myśli błądziły.

Nagle usłyszałem jej głos: - Jak panu idzie pisanie opowieści, nad którą pan ostatnio pracuje?

Moje zdziwienie rozpłynęło się w ciemności. Nagle pojawiły się w mojej głowie rozmaite hipotezy, a pośród nich też niepokojące myśli. Uciszyłem je i opanowanym głosem odpowiedziałem, że pisanie nie idzie mi dobrze.

Możliwe, że tym pytaniem chciała nawiązać do już wcześniej poruszonej sprawy. Wiem - odpowiedziała. - Ale co? - Że pisanie opowieści nie idzie panu za dobrze. - Skąd o tym wiesz? - Ta sterta śmieci za pańskim domem. Chodzę tam szperać. Ostatnio leżą tam całe stosy pomiętych i poszarpanych kartek.

Czyli biedaczka grzebie w śmieciach! Zupełnie zapadłem się w ciemność. - Ja zawsze wiem, nawet to, czy ma się pan dobrze, czy nie. - Ale skąd? - spytałem przejętym głosem. - Widziałam puste butelki, które pana wyrzucił.

Ogarnął mnie śmiech. Śmiech człowieka tonącego w ciemności. Przez chwilę mój śmiech błądził w tej ciemności, słabł, po czym zaniknął. Śmiech był bezdźwięczny, ale 
możliwe, że Panna Głód go usłyszała. Też się śmiała. W jej śmiechu i głosie było światło. - A jak obecnie się miewam? - Ostatnio niezbyt dobrze i to dlatego przyszłam się z panem spotkać. - Ale dlaczego tutaj, a nie u mnie w domu, przecież ja spędzam tam całe dnie. - Wiem, ale pomyślałby pan, że przyszłam żebrać. Nie rozmawiałby pan ze mną otwarcie, nie przyjął mnie dobrze, mogłabym panu śmierdzieć i byłby pan podejrzliwy. Tutaj, w tych ciemnościach, na tej skale, siedzimy razem jak dwoje równych sobie. Jestem od pana młodsza, mogłabym być pana córką lub wnuczką, ale nie ma pan nade mną przewagi. No i ten pana pokraczny pies ${ }^{37}$, Gogo. Czy pozwoliłby nam rozmawiać? Z daleka mnie wywęszy i ujada jak oszalały. Nawet nie pozwala mi spokojnie szperać w pana śmieciach. Tylko nocą mogę zbierać pana kartki.

Mówiła o smrodzie, o śmieciach, o moim psie Gogo, a ja czułem się tak, jakby ktoś opowiadał mi bajki o księżniczkach. Zapragnąłem przymknąć oczy, położyć się na tej skale i powiedzieć: „Proszę, mów mi jeszcze o śmieciach”. Ale uznałem, że byłoby to niestosowne. Dziwne, że przedtem nie zauważyłem jej przy śmieciach za domem. Po chwili namysłu zawstydziłem się. Przecież na pewno ją widziałem. Nie poznałem jej. Codziennie, przynajmniej ze dwa razy, przechodzę obok tej sterty śmieci. Spoglądam na kobiety i dziewczyny, które w nich grzebią, patrzę na babcię, która koło nich siedzi, ciągnę psa za smycz i uspokajam go, żeby nie szczekał. Odór śmieci skrywa w sobie marazm, który opanował moją opowieść i wdziera się w moje monotonne życie. Kilka razy dziennie Gogo, otwierając tylne drzwi, wybiega na zewnątrz. Kilka razy dziennie wybiegam za nim i podejrzewam, że ci, którzy są za domem, na pewno się zastanawiaja, skąd tyle wigoru u takiego staruszka. Czy on nie ma nic innego do roboty? Za każdym razem te śmieci na tyłach wydają się stertą wyrzuconej rzeczywistości. Panna Głód na pewno nieraz mnie widziała. I ja również musiałem ją widzieć. Dlaczego jej nie rozpoznałem? Dlaczego księżniczka o wielkich oczach i z czerwoną wstążką nigdy nie przyciągnęła mojej uwagi? Złościłem się z powodu mojej ślepoty i wstydziłem się. Dusza pragnęła, bym prosił o przebaczenie, ale wydawało się to nie na miejscu. - Tylko tutaj, siedząc po ciemku na tej skale, mogę z panem rozmawiać o takich sprawach, patrząc, jak pan spogląda w dół na te mrugające w oddali światła slumsów, jak pan się droczy z myślą, żeby w nie skoczyć, jak również bawi się tą myślą i innymi na mój temat...

Nie potrafiłem nazwać dźwięku, który niespodzianie wyszedł z moich ust, ale musiało w nim być coś, co przyprawiło Pannę Głód o śmiech. Przestała się śmiać i rzekła: - Co pana tak dziwi? Jeśli nachodzą pana myśli, by się rzucić z tej skały w slumsy, to czemu mnie mają nie nachodzić?! Wiadomo, jest pan pisarzem, jest pan starszy, jest pan zblazowany, ale to nie znaczy, że to, co panu przychodzi do głowy, nie może pojawić się też u kogoś innego. Możliwe, że to w tej skale jest coś takiego, a z pana

37 Posiadanie zwierząt domowych jest mało rozpowszechnione w Indiach i świadczy o zamożności narratora i jego wysokim statusie społecznym. 
umysłem, jak i z moim, wszystko jest w porządku. Tak jak z tymi slumsami. Tak samo jak i z tymi ciemnościami.

Czegóż to ona nie mówiła. Patrzyłem na nią oszołomiony. W jaki sposób ta mała dziewczynka stała się tak dorosła! Wiedziała wszystko. Z jaką prostotą jej drobne usta wypowiadały te górnolotne myśli. I te przemyślenia były w moim stylu. Może je skopiowała. Jak posiadła taką wiedzę? Ze śmieci? Czemu była w takim ciele? Niezliczona ilość złowieszczych pytań dręczyła moją wyobraźnię. Oczy Panny Głód lśniły w ciemności niczym dwie gwiazdy. Miałem ochotę wyciągnąć rękę i dotknąć jej oczu. Teraz nabrałem pewności, że żadnym zdaniem ani gwałtownym ruchem jej nie spłoszę. Ta dziewczynka była niesamowita. Ludzie niezwykli nie należą do żadnej kasty, nie mają wieku, nie mają ani kraju, ani obyczaju. Byłem już gotów przyjąć do wiadomości, że to nie jest zwykła dziewczynka, tylko jakaś wróżka w ciele dziewczynkỉ3. Mając tę myśl na uwadze, spytałem: - Naprawdę zbierasz śmieci? - A co bym innego mogła robić? Jestem biedna, niewykształcona, gdybym nie zbierała śmieci, to co bym robiła? Cała moja rodzina tak pracuje. Mogłabym też nazywać się Panna Smród. Mieszkańcy slumsów tak nazywali moją mamę. Jej się to wydawało okropne, a mnie nie. Owszem, to brudne zajęcie, ale nie jest trudne. Zresztą jestem ekspertką w tej dziedzinie. Możliwe, że najlepsza ze mnie Panna od Śmieci w całym mieście. Na pierwszy rzut oka wiem, co się opłaca podnieść, a co nie. Nie potrzebuję grzebać w śmieciach tak jak inni. A czasami trafiają się naprawdę fantastyczne rzeczy. Nasza lepianka to prawdziwa galeria osobliwości. Nigdy nie brakowało mi zabawek. Ani jedzenia. Ani też ubrań. Tę wstążkę, jak i sukienkę znalazłam w stercie śmieci za pana domem. Proszę nie patrzeć na moje bose stopy. Po prostu lubię chodzić boso. Mam kilka par butów, mniejszych czy większych. Ale to żadna satysfakcja, gdy żaden cierń nie skaleczy mnie w stopę. Dzisiaj ludzie tak dużo nieuczciwie zarabiają, że bezmyślnie wyrzucają wszystko bez opamiętania. Mama zawsze chwaliła władze miasta za to, że nie wywożą śmieci. Za każdym razem znajdujemy wszystko, co nam potrzebne. Wcześnie rano. Tylko trzeba być cierpliwym. Mama zachowała nawet kilka rzeczy znalezionych na śmietniku z myślą o moim posagu. Wciąż powtarzała: córko, patrz tylko, dam ci tak wspaniały posag, że ci wszyscy bogacze się zdziwią. Chodzi mi o to, że ta praca to świat sam w sobie. Pan go nie zna, więc odczuwa pan litość wobec nas. Co prawda śmieciarze żyją w niedostatku, ale bogacze zarabiają na nich krocie. Dla mnie ta praca jest rodzajem sztuki. Pan jest pisarzem, a ja zbieram śmieci. Na samą myśl o śmieciach ślina mi cieknie, a pana pewnie to przyprawia o mdłości.

Chciałem położyć rękę na jej ustach. Nie położyłem. Pomyślałem, że nie wypada. Nie na mdłości, ale na płacz mi się zbierało. Gdyby nie te ciemności, to byłoby mi bardzo

${ }^{38} \mathrm{~W}$ oryginale parī, rodzaj indyjskiej wróżki lub rusałki; postać wywodząca się z perskiej mitologii. 
trudno. Żeby taka kochana dziewczynka musiała jeść czyjeś splugawione resztki39. Ile to kochanych dziewczynek musi jeść resztki po kimś. Miałem ochotę płakać, wstydziłem się i byłem zły. Moje życie pisarza-myśliciela, to wszystko wydawało mi się nieprzyzwoite. Ale ani przez chwilę nie mogłem zapomnieć, że nie jestem w stanie nic zrobić ani dla tej słodkiej wróżko-dziewczynki, ani też żeby się uwolnić od mojej niegodziwej pracy pisarza. Niecierpliwiłem się. Chciałem nagle wstać i uciec do domu, jako że w domu najlepiej. Panna Głód z pewnością odgadła moją słabość, jak i mój dyskomfort.

Rzekła dobrodusznie: - Pan mi zadał pytania, a ja odpowiedziałam i wydaje mi się, że trochę za dużo powiedziałam, ale pan musi być twardy, musi pan być na tyle odważny, aby wszystko zobaczyć i usłyszeć. W końcu jest pan pisarzem i swoje sterty śmieci za domem również pan widzi kilka razy w ciągu dnia, mnie też musiał pan widzieć. Ja pana kilka razy widziałem, z tym pokracznym psem lub bez, jak stał pan przy tej staruszce, kiedy szukała czegoś lub zjadała jakieś resztki jedzenia. Cóż, pana śmieci są niesamowite, niebywałe rzeczy tam można znaleźć! Wspaniałe papiery! Ja nie sprzedaję tych wymiętych i rozerwanych kartek, tylko przynoszę je do domu, składam w całość i czytam. Niektóre kawałki są tak małe, że pomimo niezliczonych prób nie udało mi się ich złożyć w całość, a niektóre tak niekompletne, że nawet po sklejeniu ich nie odczytam. Ale niektóre są też takie, zwłaszcza te, które są tylko zmięte, że jak tylko się je rozłoży, można je czytać bez problemu. Jest w nich tam wiele rzeczy, a niektóre z nich powracają i to dzięki nim wiem, że ani z panem nie jest dobrze, ani z pisaniem tej powieści, którą pan nazwał "Głód".

Tym razem nie pozwoliłem sobie na zadumę ani fascynację tym, jak pieczołowicie zbiera moje podarte zapiski i się nimi opiekuje. To, co powiedziałem, brzmiało mniej więcej tak: - Nie wierzę, że naprawdę grzebiesz w śmieciach. Nie wierzę, że zjadasz czyjeś resztki. Nie wierzę, że zbierasz moje powyrzucane, pomięte i rozerwane papiery, czytasz z nich o mnie i o mojej pracy. Nie wierzę, że mieszkasz daleko na dole w slumsie i że nazywasz się Panna Głód. Nie wierzę, że siedzisz naprzeciwko mnie. Ten język, ta ironia, te dobre maniery, ten głos, ten śmiech, ta pewność siebie, te oczy, skąd się wzięły u jakiejś brudnej i skalanej dziewczynki, buszującej po śmietnikach? Ze śmieci? Ze slumsów? Z tej rodziny, co żyje ze śmieci? Nie wierzę w to. Powiedz prawdę, kim jesteś?

Trząsłem się, mój głos również. Jak dotychczas wszystko to traktowałem pół żartem, pół serio. Może nie żartem, ale naturalnie. Nawet nie naturalnie, ale z niedowierzaniem zmieszanym z ciekawością. Ale to, że je resztki ze śmietnika i czyta moje zmięte papiery i je skleja, całkowicie mnie wytrąciło z równowagi. A teraz wyciągnęła ręce i chwyciła moje. W jej dwóch małych szorstkich dłoniach moje miękkie i trzęsące się dłonie drżały, jak ranne ptaki. - Ojej - powiedziała - ale się pan przejął! Pan całkiem traci równowagę.

${ }^{39}$ Słowo bez odpowiednika polskiego. Jüṭhan oznacza tak samo resztki jedzenia, jak i pewien rodzaj nieczystości rytualnej. Spożywanie resztek po kimś, tym bardziej po nieznanej osobie, stanowi skrajną nieczystość, co pokazuje tutaj niską przynależność kastową dziewczynki. 
Jak pan mi nie wierzy, to nic nie szkodzi, ale po co tak dramatyzować? Pan przecież zna życie, jest pan pisarzem, powinien pan już mieć jakieś doświadczenie z ludźmi wszelkiego sortu i zapewne pan je ma. Jak nie w rzeczywistości, to w wyobraźni, wszelkiego rodzaju cuda się zdarzają, nie powinien więc pan się tak obruszać z pierwszego lepszego powodu. Zgoda, nie wierzy pan, ale po co się tak złościć? Na kogo? Na mnie? Na Pannę Głód? To dobrze, niech pan na mnie mówi Panna Grób! A teraz, no proszę się uśmiechnąć. Proszę głęboko oddychać. Jeszcze raz. Jeszcze raz. Proszę spojrzeć, już się pan mniej trzęsie. Artyści sami są magikami, więc nie powinni wątpić w żadne inne czary. Wiem, że obecnie jest pan sam całymi dniami, siedzi pan zgarbiony nad swoim biurkiem, za mało pan je, za dużo pije, dlatego też jest pan nerwowy i dlatego też praca nad pana opowieścią nie idzie do przodu, ale ja mogę panu pomóc, to też dzisiaj z panem...

I dalej mówiła, mówiła... a ja żałowałem, że zabrałem głos. W jej słowach była magia, w uścisku jej dłoni również. Próbowała za pomocą tej magii zwalczyć mój brak wiary. Ja czerpałem siłę z jej rąk i słów. Zapragnąłem razem z nią skoczyć w mrugające światła slumsów w oddali. Powoli dochodziłem do siebie, ale mój sceptycyzm nie miał dokąd się ulotnić. Sam siebie przekonywałem, że nie mam prawa rugać tej dziewczynki, nieważne, czy jest jakąś wróżką, czy duchem, czy wierzę w to, co mówi, czy nie. Miała na mnie wpływ, lepiej ten wpływ wykorzystać, zamiast go zwalczać. Myśląc o tym wszystkim, słuchając tego wszystkiego, prawie wróciłem do swojego normalnego stanu. - Powinienem był panować nad sobą - rzekłem. - Nic nie szkodzi.

Potem puściła moją dłoń. Nadal czułem wspaniałą szorstkość jej dłoni na własnych. Milczeliśmy przez jakiś czas. Długo wpatrywałem się w jej ogromne oczy, a ona w moje małe.

W końcu spytała: - W sumie to czemu pan mi nie wierzy?

Nie byłem gotowy na takie pytanie. Chwilę wcześniej również mi je zadała. Wtedy jeszcze nie wprost, aby mnie oszczędzić, a teraz otwarcie. A odpowiedź splatała się z całym moim życiem. Było niemożliwe, abym w tym czasie, tu na poczekaniu rozwiązał ten supeł swojego życia. Milczałem. Myślałem, że z grzeczności już nie powtórzy pytania. Nie rozczarowała mnie. Obawiałem się, że zgasiłem czar tego wieczoru, i chcąc oddalić to niebezpieczeństwo, spytałem: - W jakim jesteś wieku? - A tak z dwanaście, trzynaście lat, jakoś tyle. A pan? - A tak z sześćdziesiąt jeden, sześćdziesiąt dwa lata, jakoś tyle. - Porusza się pan jak szesnastolatek.

Uśmiechnąłem się. O tej mojej słabości też wiedziała. - Jeśli pan obiecuje, że nie będzie się pan denerwować, to mogę mówić dalej. - Obiecuję. - Dlaczego jest panu tak ciężko skończyć tę opowieść?

Oczywiste było, że na to pytanie również nie byłem gotowy. Miałem ochotę powiedzieć, że dla mnie napisanie każdej opowieści jest trudne, właśnie w trudzie jest prawdziwa przyjemność, każdemu prawdziwemu artyście jest ciężko itp., itd. Gdyby 
na jej miejscu siedział ktoś inny, to może posłużyłbym się właśnie wypowiedzią w tym stylu, aby podtrzymać rozmowę. Ale to Panna Głód siedziała naprzeciwko mnie - ta, która grzebała w śmieciach, która sklejała moje rozdarte manuskrypty, moja towarzyszka tego wieczoru.

Więc powiedziałem, że w sumie to nie wiem dokładnie, nie chcę wiedzieć, nie chcę też nic mówić. Boję się, że wówczas opowieść umrze i wtedy ona już nie znajdzie w śmieciach tych pomiętych, brudnych papierów. - To proszę nie mówić. Uzależniłam się od rozwijania tych brudnych zapisków. W mojej lepiance jest ich cała sterta i nieustannie rośnie. Gdyby mama nadal żyła, to byłby to problem. - Co się stało twojej mamie? - Umarła. - Na co? - Na czerwonkę.

Nie miałem odwagi pytać o ojca, ale ona jakby domyśliła się treści mojego niewypowiedzianego pytania. - Ojca również nie mam. To znaczy, nie wiem, kim jest ani gdzie żyje. Mama nigdy o nim nie wspominała. Ludzie ze slumsów złościli mnie, mówiąc, że jestem bękartem. Odwdzięczałam się wyzwiskami. Wtedy jeszcze tym bardziej mnie nękali. Teraz już zmądrzałam. Siedzę cicho. Pewnego dnia widziałam matkę we śnie. Przemówiła mi do rozumu, bo inaczej tobym zwariowała. Teraz ludzie przestali mnie prześladować. Mówią, że to już ich nie bawi. Czegóż to by ludzie nie zrobili dla zabawy.

Jej ostatnie zdanie było jakby przepełnione wiedzą o życiu. Zapewne odgadła, że mój stan znowu się pogarsza. Może dlatego odezwała się niepewnym głosem: - Ja również lubię pisać.

Nie zdziwiło mnie to. Milczałem. - Pewnie zastanawia się pan, kto nie lubi?

Nie potrafiłbym wyjaśnić, o czym teraz myślałem. Aby wyrwać się z tych swoich mrocznych myśli, spytałem: - O czym piszesz? - Jak na razie to gromadzę papier i doświadczenia.

To ostatnie słowo „doświadczenie”, które wydobyło się z jej ust, wzbudziło w moich mrocznych myślach magiczne migotanie niczym świetlik. Zdawało mi się, że naprzeciwko mnie siedzi uosobienie uwodzicielskiego talentu, czule żartujące z siebie i ze mnie. Znów poczułem się lekki, promienisty. Pomyślałem, że wezmę ją ze sobą do domu i nakarmię. Najpierw każę jej umyć ręce. Nie, najpierw powiem: „Idź szybko się umyj". Dam jej koszulę i spodnie do ubrania. Powiem, aby wyrzuciła swoje ubrania do śmieci. Zatrzymam tylko czerwoną wstążkę. Jej ciało pozbawione brudu rozkwitnie jak kwiat. Zapiszę ją do jakiejś dobrej szkoły.

Daleko odpłynąłem myślami i nie potrafiłem się zatrzymać, chociaż wstydziłem się ich romantycznego zabarwienia. Obawiałem się, że Panna Głód nagle mnie spyta, co się tak rozmarzyłem.

Ale ona bardzo dojrzałym tonem o coś innego spytała: - Pewnie pan mi nie uwierzy, ale mogę panu pomóc.

Wzdrygnąłem się i oprzytomniałem. Czekając na moją odpowiedź, Panna Głód mi się przyglądała. - Czy ci wierzę, czy nie, przyjmuję twoją pomoc. 
Panna Głód podniosła się i stojąc na skale, poprawiła swoją niebieską spódnicę, przeciągnęła się, uśmiechnęła i powiedziała: - A więc będzie pan musiał pójść ze mną do moich slumsów, pobyć ze mną kilka dni w mojej lepiance, pozbyć się tych ubrań i założyć brudne, spać na ulicy przy rynsztoku, zapomnieć o swoim domu, wrócić do tych dni, kiedy był pan młody i kiedy głód zawsze panu towarzyszył. Kiedy pan marzył, aby położyć mu kres. Będzie pan musiał jeść splugawione resztki po obcych ludziach i powstrzymywać małości. Będzie pan musiał przekroczyć granice swojej wyobraźni.

Przez pewien czas mówiła dalej, a ja słuchałem w ciszy, z opuszczoną głową. Jej głos dochodził do mnie jakby z nieba. Byłem gotów wyznać, że akceptuję wszystkie te warunki, ale taka deklaracja nie wychodziła z moich ust.

Nagle ucichła. Podniosłem głowę. Uśmiechała się. Dostrzegła moje zakłopotanie. Niech pan nie podejmuje decyzji pochopnie. Pewnej nocy przyjdę do pana we śnie, a do tego czasu proszę rozważyć w głębi duszy moją propozycję.

To powiedziawszy, zeskoczyła ze skały i w podskokach zbiegła ścieżką w dół do mrugających świateł slumsów. Siedziałem tak tam jeszcze jakiś czas, po czym wstałem i poszedłem do domu.

Sporo czasu minęło od tego wydarzenia. Każdej nocy czekam na ten sen, w którym nadejdzie Panna Głód, a ja zakomunikuję jej swoją decyzję.

\section{Bibliografia}

\section{Teksty źródłowe}

Vaid, Krishna Baldev. 1999. एक बदबूदार गली - Ek badbūdār galī. W मेरा दुश्मन - Merā Dushman, सम्पूर्ण कहानियां - Sampūrṇ Kahāniyã Part 1. New Delhi: National Publishers.

Vaid, Krishna Baldev. 1999. भूख कुमारी के साथ एक शाम - Bhūkh kumārī ke sāth ek shām. W Rāt kī Sair, सम्पूर्ण कहानियां - Sampūrn Kahāniã Part 2. New Delhi: National Publishers.

Vaid, Krishna Baldev. 2010. हिंदी-उर्दूसंवाद - Hindī-Urdū sanvād. W ख़ाली किताब का जादूXālī kitāb kā jādū. Hariyana: Penguin Books India.

\section{Opracowania}

Bartmiński, Jerzy. 2007. Stereotypy mieszkają w języku. Studia etnolingwistyczne. Lublin: Wydawnictwo Uniwersytetu Marii Curie-Skłodowskiej.

Bańko, Mirosław. 2016. Forma i znaczenie w adaptacji zapożyczeń. W Diana Svobodová, Joanna Rączaszek-Leonardi, Marcin Tatjewski. Nie całkiem obce. Zapożyczenia wyrazowe w języku polskim i czeskim, red. Mirosław Bańko, 53-70. Warszawa: Wydawnictwa Uniwersytetu Warszawskiego.

Bednarczyk, Anna. 2008. W poszukiwaniu dominanty translatorskiej. Warszawa: Wydawnictwo Naukowe PWN.

Bhardwaj, Ashutosz. 2020. „Krishna Baldev Vaid's Novels Stepped into Uncharted Zones”. The Indian Express (February 8). Dostęp: 11.07.2021. https://indianexpress.com/ article/opinion/columns/krishna-baldev-vaid-dead-novel-literature-6256655/. 
Bochnakowa, Anna. 2012. Wyrazy francuskiego pochodzenia we współczesnym języku polskim. Kraków: Wydawnictwo Uniwersytetu Jagiellońskiego.

Brzozowska, Małgorzata. 2009. Etymologia a konotacja słowa. Studia semantyczne. Lublin: Wydawnictwo Uniwersytetu Marii Curie-Skłodowskiej.

Cielas, Hermina. 2016. Betel Chewing in kāvya Literature and Indian Art. W A World of Nourishment. Reflections on Food in Indian Culture, edited by Cinzia Pieruccini, and Paola M. Rossi, 163-176. Milan: Ledizioni.

Czuruta, Olga. 2015. Przekład tekstu wielokulturowego albo polilog międzykulturowy. W Przekład, język, kultura, red. Roman Lewicki, 85-95. Lublin: Wydawnictwo Uniwersytetu Marii Curie-Skłodowskiej.

Everaert, Christine. 2010. Tracing the Boundaries between Hindi and Urdu: Lost and Added in Translation between $20^{\text {th }}$ Century Short Stories. Brill: Leiden-Boston (Brill's Indological Library, 32).

Kaźmierczak, Marta. 2016. „Na peryferiach teorii - trzeci język w przekładzie”. Między Oryginałem a Przekładem XXII, nr 1(31): 61-89.

Kilgarriff, Adam. 2007. „Googleology is Bad Science”. Computational Linguistics 33 (1): 147-151. Milewski, Tadeusz. 2008. Językoznawstwo. Warszawa: Wydawnictwo Naukowe PWN.

Montaut, Annie. 2016. Why and How: Translating from these 'Other' Languages? W Translating Bharat, Reading India, edited by Neeta Gupta, 58-71. New Delhi: Yatra Books.

Nagórko, Alicja. 2004. „Wstęp”. W Dystynktywny słownik synonimów, red. Alicja Nagórko, Marek Łaziński, Hanna Burkhardt, VII-XIV. Kraków: Universitas.

Nida, Eugene A. 2009. Zasady odpowiedniości. Tłum. Anna Skucińska. W Współczesne teorie przekładu. Antologia, red. Piotr Bukowski, Magda Heydel (red.), 51-69. Kraków: Znak.

Newmark, Peter. 1988. A Textbook of Translation. New York: Prentice Hall.

Pant, Saumya. 2010. „Outcry Over Denial of Award to Writer”. India Today (March 15). Dostęp: 11.07.2021. https://www.indiatoday.in/latest-headlines/story/outcry-over-denial-of-award-to-writer-69447-2010-03-15.

Stachowski, Stanisław. 2007. Słownik historyczny turcyzmów w języku polskim. Kraków: Księgarnia Akademicka.

Stasik, Danuta. 2008. „Dialekty, odmiany, style języka hindi w kontekście wielojęzyczności”. W Języki Azji i Afryki w komunikacji międzykulturowej, red. Nina Pawlak, 145-157. Warszawa: Wydawnictwa Uniwersytetu Warszawskiego.

Stępień, Jakub. 2014. Hinduski fundamentalizm religijny. Kraków: Księgarnia Akademicka. Svobodová, Diana. 2016. Adaptacja formy i znaczenia: studia przypadku. W Diana Svobodová, Joanna Rączaszek-Leonardi, Marcin Tatjewski. Nie całkiem obce. Zapożyczenia wyrazowe w języku polskim i czeskim, red. Mirosław Bańko, 71-101. Warszawa: Wydawnictwa Uniwersytetu Warszawskiego.

Urdang, Laurence. 1978. Introduction. W The Synonym Finder, edited by Jerome Irving Rodale, iii. Emmaus, Pa: Rodale Press.

Vaid, Krishna Baldev. 2017. In Conversation with Krishna Baldev Vaid (April 10). Dostęp: 11.07.2021. https://penguin.co.in/in-conversation-with-krishna-baldev-vaid.

\section{Słowniki}

Asad Ali Sayyedd. 2018. Vyavaharik Urdū-Hindī Shabdkosh. Delhi: Rajpal \& Sons. Dās Śyāmsundar. 1965-1975. Hindī śabdsāgar. Kāśî: Nāgrī Pracāriṇī Sabhā. 
Haqqee Shanul Haq. 1995. Oxford English-Urdu Dictionary. Oxford: Oxford University Press.

Kuczkiewicz-Fraś, Agnieszka. 2012. Perso-arabic Loanwords in Hindustani. Kraków: Księgarnia Akademicka.

Kumar, Arvind. 2015. Arvind Word Power English-Hindi a Dictionary with a Difference. New Delhi: Arvind Linguistics Private Limited.

McGregor, R.S. 1993. The Oxford Hindi-English Dictionary. Oxford: Oxford University Press. Platts, John Thompson. 2015. A Dictionary of Urdu, Classical Hindi and English. London: W.H. Allen \& Co., Oxford University Press.

Shukl, Sacchidaanand, Kuddusi, Zahir Hasan. 2017. Urdū-Hindī Shabdkosh. New Delhi: Unicorn Press.

Steingass, Francis Joseph. 2019. A Comprehensive Persian-English Dictionary, Including the Arabic Words and Phrases to Be Met with in Persian Literature. London: Routledege \& K. Paul.

Sulaiman, Haïm. 2019. New Persian-English Dictionary. Teheran: Librairie-imprimerie Béroukhim.

\section{Korpusy językowe}

HindiMonoCorp. Dostęp: 11.07.2021. https://indat.mff.cuni.cz/services/kontext/first_form ?corpname=hindmonocorp_05_m.

HindiWaC. Dostęp: 11.07.2021. https://www.sketchengine.eu/hindiwac-hindi-corpus/.

Narodowy Korpus Języka Polskiego. Dostęp: 11.07.2021. http://www.nkjp.uni.lodz.pl/.

UrduCorp. Dostęp: 11.07.2021. https://lindat.mff.cuni.cz/services/kontext/first_form?corpname=urducorp_ur_m. 